\title{
Searching for the right application: a technology development review and research agenda
}

\author{
Stefano Magistretti ${ }^{1}$, Claudio Dell'Era ${ }^{1}$, Roberto Verganti ${ }^{1}$ \\ ${ }^{1}$ School of Management, Politecnico di Milano - Piazza L. da Vinci, 3220133 Milano Italy
}

This is a post-peer-review, pre-copyedit version of an article published in Technological Forecasting and Social Change. The final authenticated version is available online at: https://doi.org/10.1016/j.techfore.2019.119879

Please cite as: Please cite as: Stefano Magistretti, Claudio Dell'Era, Roberto Verganti, "Searching for the right application: A technology development review and research agenda" Technological Forecasting and Social Change, Volume 151, 2020, 119879, ISSN 0040-1625, https://doi.org/10.1016/j.techfore.2019.119879.

\begin{abstract}
Today's world is characterized by a continuous evolution in the demand and supply of new technology solutions, challenging the way companies pursue and manage technology development. Indeed, companies can no longer take decades to develop new technologies, but are compelled to deliver technologies in a short space of time. Despite the ample literature on the different technology development processes, the main factors influencing the creation of technological solutions remain unclear. The problem is no longer identifying a new process for developing a technology, but understanding which elements can guide the selection of the best approach for the situation faced. The aim of this study is therefore to provide a systematic literature review of technology development studies to contribute to shed lights on how companies can develop technology to foster innovations in a society that is continuously evolving its technological needs. The analysis of 187 articles highlights that process, organization, and knowledge are the three key dimensions that influence every technology development process. Thus, two main dichotomies emerge (i) linear vs iterative on the process level, (ii) designing vs finding on the knowledge level. Accordingly, we propose a research agenda based on a framework mapping the four resulting approaches.
\end{abstract}

Keywords: Technology Development; Technology Management; Technological Innovation; Open Innovation; Systematic Review;

\section{Introduction}

Today's world is characterized by a continuous evolution in the demand and supply of new technological solutions (Boon et al., 2008). People and companies are surrounded and immersed in a multiplicity of technologies (Parasuraman, 2000), and the efficient and effective 
development of such technologies is vital for newcomers. This abundance of technological options challenges the way companies have traditionally pursued their development processes (Cooper and Sommer, 2016). High market demand for new technologies and a more fluid and dynamic environment have led to a misalignment between traditional and new technology development perspectives. Indeed, the literature shows that companies pursue technology development using mainly two approaches: normative and exploratory (Kahn, 1992). Normative development occurs after selection and begins from the future by tracing back the steps needed to reach the endpoint (Dreborg, 1996). Conversely, exploratory development begins from the present to explore the future, constructing the development path from the current to the prospective (Kahn, 2002). As is evident, both approaches assume that the development process is linear and sequential, and inherent in approaches such as stage-gate (Cooper and Kleinschmidt, 1986) or technology integration (Iansiti, 1995), formerly considered the best way to develop new technological solutions.

The advent of new digital technologies that allow companies to experiment with radical and incremental technologies more expeditiously has challenged this linear perspective and also led to the emergence of different methodologies (Arbesman, 2016). As Nambisan et al. (2017) report, the rapid and pervasive digitization process requires new innovation methodologies for technology development. In particular, researchers have attempted to define the business impact of digital technologies as an enabler of more fluid and less bounded entrepreneurial processes and outcomes that allow a continuous evolution of the scope, features, and value of the offering (Nambisan, 2017). Thus, digital technologies are recognized by researchers in the field as the practices, processes, and principles that underlie the effective orchestration of digital innovation (Nambisan et al., 2017). Digital technologies also influence the organizational role of technology research and development (R\&D) teams (Sakkab, 2002) in relation to the internal and external development of technology solutions (Denicolai et al., 
2016), and knowledge creation and management. In addition to the process and organization dimensions, other studies analyze the timing of the introduction of new technology solutions as a key driver of technology development (Markman et al., 2005). Indeed, numerous researchers reveal that good timing in technology development can help generate competitive advantage (Schilling, 2002). However, this no longer guarantees that customers will perceive the company as innovative (Barczak et al., 2009), as people seek not just mere innovations but meaningful ones (Dahlin and Behrens, 2005; Verganti, 2009, 2017).

Despite these contributions, no helpful and inspiring insights are currently available to researchers and managers on how to move from finding new applications for a technology to searching for the right application of technologies; in other words, how to foster technology development to enhance the discovery of opportunities hidden within the technologies (Dell'Era et al., 2017). This implies that deeper knowledge is required to manage technology development on the three aforementioned dimensions: (i) process, (ii) organization, (iii) knowledge. Indeed, companies can no longer take years or even decades to develop new technologies just to improve functional performance but are compelled to deliver technological innovations in a short space of time. This is due to the challenge the digital world imposes on the technology development process, which is no longer linear, and the continuous market requests.

The relevance of these issues is further emphasized when considering that in the last few years, researchers and practitioners have recognized that technologies frequently offer greater opportunities than mere substitution (Chesbrough, 2003; Proni and Carimati, 2007; Danneels, 2007; Verganti, 2011; Buganza et al., 2015; Dell'Era et al., 2017). These reasons are why researchers, organizations, and scholars in the innovation and technology management field seek an interpretative framework that enables effectively mastering technology development. 
Thus, the objective of this study is to review the extant literature on technology development, focusing mainly on the process and organization dimensions. In terms of academic relevance, this study aims to explore and enrich current knowledge on technology development by proposing an interpretative framework and the state-of-the-art of this broad literature stream. In terms of practical relevance, the expected outcome is a framework that can support companies in accelerating the process of understanding and exploiting technologies.

\section{Theoretical Background}

The body of literature on technology management is vast (Leonardi, 2008). Given our objectives, we consider the most relevant streams of the overarching technology management literature. In more detail, considering the aim of proposing an interpretative framework for practitioners and academics, we refer in this section mainly to seminal papers in the innovation and technology management research field.

Although several scholars have studied the technology management literature, the heterogeneous classifications point to the importance of a new perspective that is more in line with emergent market needs.

One of the most interesting perspectives is that which categorizes technology management into two main streams: technology selection (Armstrong, 2001; Cuhls, 2003; Scapolo and Porter, 2008) and technology development (Inasiti, 2000; Klein, and Kleinman, 2002; Thomke, 2003; Govindarajan and Kopalle, 2006; Van de Vrande et al., 2011; Soukhoroukova et al., 2012), aimed at enriching the knowledge of researchers on the aforementioned process dimension. Indeed, selection and development are two well-defined and sequential technology management moments. Specifically, the first relates to foreseeing a potential in the technology, the second relates to exploring the technology to understand how it can be exploited and integrated (Danneels and Frattini, 2018). 
The review of the seminal papers highlights the considerable attention of scholars on the process dimension of technology development, identifying selection as the first step in the technology management process (Adner and Levinthal, 2001); in other words, the technology chosen from among all those available in an uncertain environment (Fleming, 2001; Krishnan and Bhattacharya, 2002). Relatedly, several studies attempt to understand the impact of a known technology in the future, i.e., technology forecasting (Cuhls, 2003; Eto, 2003), or which technologies companies should invest in to ensure they can introduce a new product in the future that leverages the technology, i.e., technology foresight (Reger, 2001; Calof and Smith, 2010; Linstone, 2011). An extensive study in this direction is that of the Technology Futures Analysis Methods Working Group (2004) proposing an extensive review of the forecasting methodologies and tools to understand the potential value of technologies in the selection phase.

\subsection{Technology Development: Process, Organization, and Knowledge}

Moving forward in the technology management process, technology development is the second step in this sequential process. Thus, according to the new product development approach (Barnett and Clark, 1998; Cooper, 1994, 2006; Griffin 1997; Barczak et al., 2009), defined as a stage-gate methodology to develop new solutions, this moment comes after the selection and before the launch into the market. While this common approach would seem to suggest a linear and sequential technology development process, researchers and practitioners today agree that this is no longer the case (Schmoch, 2007; Ries, 2011; Knaap et al., 2016). According to Grodal et al. (2015), the technology development process is the combination of a divergent and convergent phase, and not only funneling (Twiss, 1992). Moreover, recent studies shed light on the different process dynamics that connotes the way the process is put in place (Douthwaite et al., 2001; Schmoch, 2007), greatly leveraging exploration and experimentation (Fleming, 2001; Thomke, 2003; Weng et al., 2014; Knapp et al., 2016). 
The way the development is performed in terms of dynamics has a significant impact on the organizational domains. Indeed, combining different practices is crucial to increase the effectiveness of iteration (Savino et al., 2017). Moreover, the growing debate around open innovation has highlighted the fact that in new technology development, organizations can no longer act at the individual level (Chesbrough, 2006), but need to consider the interaction of different stakeholders at different stages (Ardito et al., 2015). Moreover, when the focus moves from stage-gate (Cooper, 2006) to hybrid approaches (Cooper and Sommer, 2016; Magistretti et al., 2019), researchers note the impact not only on the sequence of phases but also on the organizational level. Indeed, the more hybrid approach suggests a different structure of the organization with dedicated roles, such as facilitators (Knapp et al., 2016), or new roles, such as scrum masters.

Furthermore, scholars highlight the knowledge dimension of the technological orientation toward the development of an organization (Gambardella and McGahan, 2010; Petruzzelli, 2011; Adner and Kapoor, 2016; Wang and Seidle, 2017). Indeed, companies focused more on the different elements of development, such as the inner features of technologies or network of knowledge sharing, to understand the impact of a distributed network of players on technology development (Chesbrough, 2006; Vanhaverbeke et al., 2014). In this direction clearly emerges the role of knowledge as a driver of success for the technology development. Indeed, this dimension is still evolving in the technology development arena, and further investigations are needed to shed light on the impact of new processes and organization, on the knowledge sources either in the creation and in the exploitation.

\subsection{Gaps in the Technology Development Literature}

While the different studies on the technology development are fundamental to understand the essence of technology management, to our knowledge, no systematic review clarifies or 
explores the underpinning characteristics of the differences between process, organization and knowledge in the development.

In particular, in the process dimension, the different dynamics underpinning the sequence of the process have been explored in the new product development but still not in pure technology development. Also, different approaches to experimentation in R\&D departments and companies have been studied by researchers (Kaplan, 1999; Thomke, 2001; Hegger et al., 2007; Akgün et al., 2007), but now a clear understanding of the relevant domains needed to support the development have been highlighted. Another inspiring element in this broad research stream is the source of knowledge that technology development leverages. In particular, some studies focus more on problem-solving as a way of designing a new application for technologies that are under development (Costantini et al., 2015). Others focus on problem framing by finding new applications by leveraging the knowledge in a new way to support the identification of new opportunities (Grodal et al., 2015; Dell'Era et al., 2017). Notwithstanding, this the relation between these two perspectives is still unclear.

This brief overview of the technology management literature illustrates the multifaceted contributions of researchers in the last decades to this relevant research field, justifying a systematic literature review to offer a clear interpretative framework to strengthen the usability of the different processes and methodologies. Adopting a systematic perspective, this review considers the different approaches proposed by analyzing (independently of the industry or the research methodology adopted) the technology development orientation and the different characteristics. Specifically, our objective is to map the state-of-the-art of the processes and methodologies in the literature to effectively and efficiently manage technology development in a continuously changing ecosystem.

\section{Methodology}


This section discusses the methodology adopted. In particular, in this review, we followed the guidelines of Tranfield et al. (2003) and adopted a systematic approach to identify the seminal contributions in the field using a sequential process to screen and select the relevant articles.

First, we identified a set of ten relevant keywords. Second, we asked experts in the field to validate the list and suggest any potential additions. This phase led to revising the initial set of keywords. Out of the initial ten, four were deemed non-relevant, and three to four new and overlapping keywords were suggested, leading to a final list of seven: technology development, technology integration, technology exploration, technology experimentation, technology implementation, technology introduction, and technology evolution.

We then used these keywords to search the Scopus database and systematically review the existing literature in the technology management field, and especially the technology development research stream. The Scopus database, used in several prior studies, is considered one of the most relevant and diffused databases for academic articles. We screened the articles by relevance using the Impact Factor (IF) of the journals as a proxy, and included only the relevant journals in our search. To set the threshold, we considered both the 2016 and the 5year IF; specifically, journals with 2016 IF higher than 2 and with a 5-year IF higher than 2.5. This reduced the list of journals to 59 including top journals with very high IF, such as MIS Quarterly and Academy of Management Review, and others, such as R\&D Management Journal and Journal of Engineering and Technology Management, not comparable in terms of IF but very relevant and focused on the technology management topic. Moreover, the Scopus search was limited to academic articles in the business, management, and accounting fields (Keupp et al., 2012), deemed the repository of real knowledge (Ordanini et al., 2008; Podsakoff et al., 2005). Thus, the total number was reduced from 1417 to 483 highly relevant articles. 
We proceeded to read the 483 articles collected to understand whether they should be considered in the study. Interestingly, these articles range over the period 1980-2018 as a natural outcome of the exclusion process due to unsatisfactory IF.

The inclusion and exclusion criteria were reviewed and selected with the same panel of experts in the field. The first exclusion criterion evaluated the relevance of the articles for the development phase. Hence, all articles related to the selection phase or other undefined phases of technology management were excluded, which resulted in eliminating 100 articles. The second criterion excluded articles that did not rely on real cases but on simulations since the review also intends to address practitioner needs. Finally, the third exclusion criterion concerns the unit of analysis, whereby all articles that only marginally centered on technology development were excluded.

Table 1. Inclusion criteria

\begin{tabular}{lll}
\hline No. & Criteria & Reason for inclusion \\
\hline 1 & Empirical Study & $\begin{array}{l}\text { Given the focus on processes, organization, and knowledge, the } \\
\text { empirical evidence is of particular interest for this review }\end{array}$ \\
\hline 2 & Research Focus & $\begin{array}{l}\text { The set of keywords previously reported stress the centrality of } \\
\text { the technological focus of the articles that are of interest for the } \\
\text { review }\end{array}$ \\
\hline
\end{tabular}

Table 2. Exclusion criteria

\begin{tabular}{lll}
\hline No. & Criteria & Reason for exclusion \\
\hline 1 & Publication Type & $\begin{array}{l}\text { Excluding books, book chapters, conference proceedings, and } \\
\text { dissertations }\end{array}$ \\
\hline 2 & Perspective Study & $\begin{array}{l}\text { Excluding articles with simulations and perspective studies that } \\
\text { do not deal with real cases }\end{array}$ \\
\hline 3 & Unit of analysis & $\begin{array}{l}\text { The research question is focused on technology development, } \\
\text { and we thus excluded all articles that are not fully centered on, } \\
\text { or only marginally address, this topic }\end{array}$ \\
\hline
\end{tabular}

Adopting these inclusion and exclusion criteria further reduced the number of relevant articles to 187 (Meier, 2011; Pittaway et al., 2004; Rashman et al., 2009; Wang and Chugh, 2014; Savino et al., 2017), considering the focus of the title and the abstract. In particular, all articles related to processes, organization of the network, and knowledge creation and sharing 
on the topic of technology development were included in the analysis. The Appendix provides a snapshot of the 187 articles included in the review on the process, organization, and knowledge dimensions.

Fig. 1 shows the increase in publications from 1980 to 2018. This trend is in line with the increasing interest of scholars and practitioners in the topic given the demand for faster ways to develop and experiment with technology, as well as the growth in both digital technologies and user demand. This creates considerable tensions for scholars to create new knowledge on how to efficiently and effectively manage technology development.

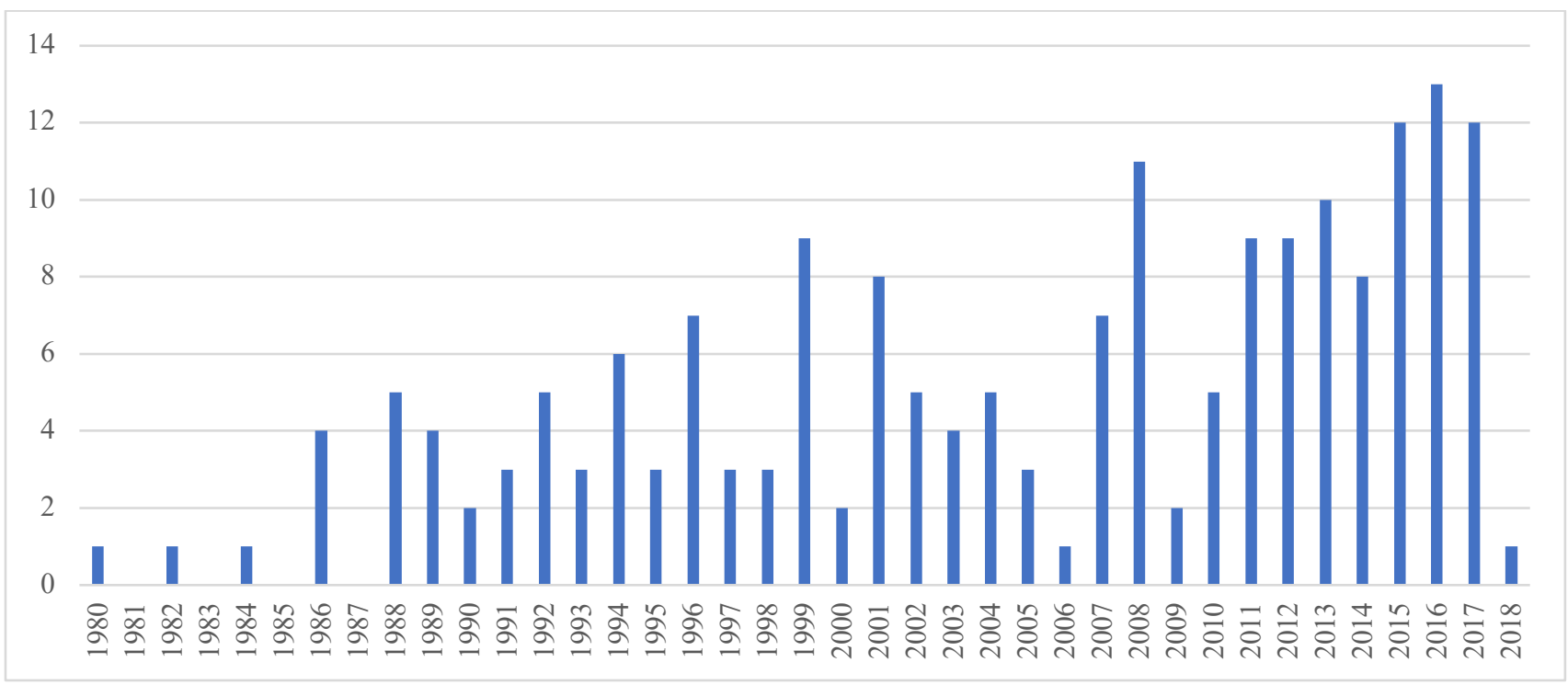

Fig.1. Relevant articles published over the period 1980-2018 in highly relevant journals.

Another important aspect of the dataset is the distribution of articles in different journals. Of note is that the majority of articles are published in journals that do not focus on academic reviews but are more oriented towards disseminating scholarly and practitioner knowledge. Second, almost $50 \%$ of the relevant articles are published in top journals in the field of innovation, and especially those more focused on technological innovation, such as Technological Forecasting and Social Change, Technovation, Research Policy, and Journal of Product Innovation Management. In fact, 35 of the articles are published in Technological 
Forecasting and Social Change, an academic journal whose main objective is publishing articles closely related to technological forecasting, methodologies, and practices to foster these aspects of innovation.

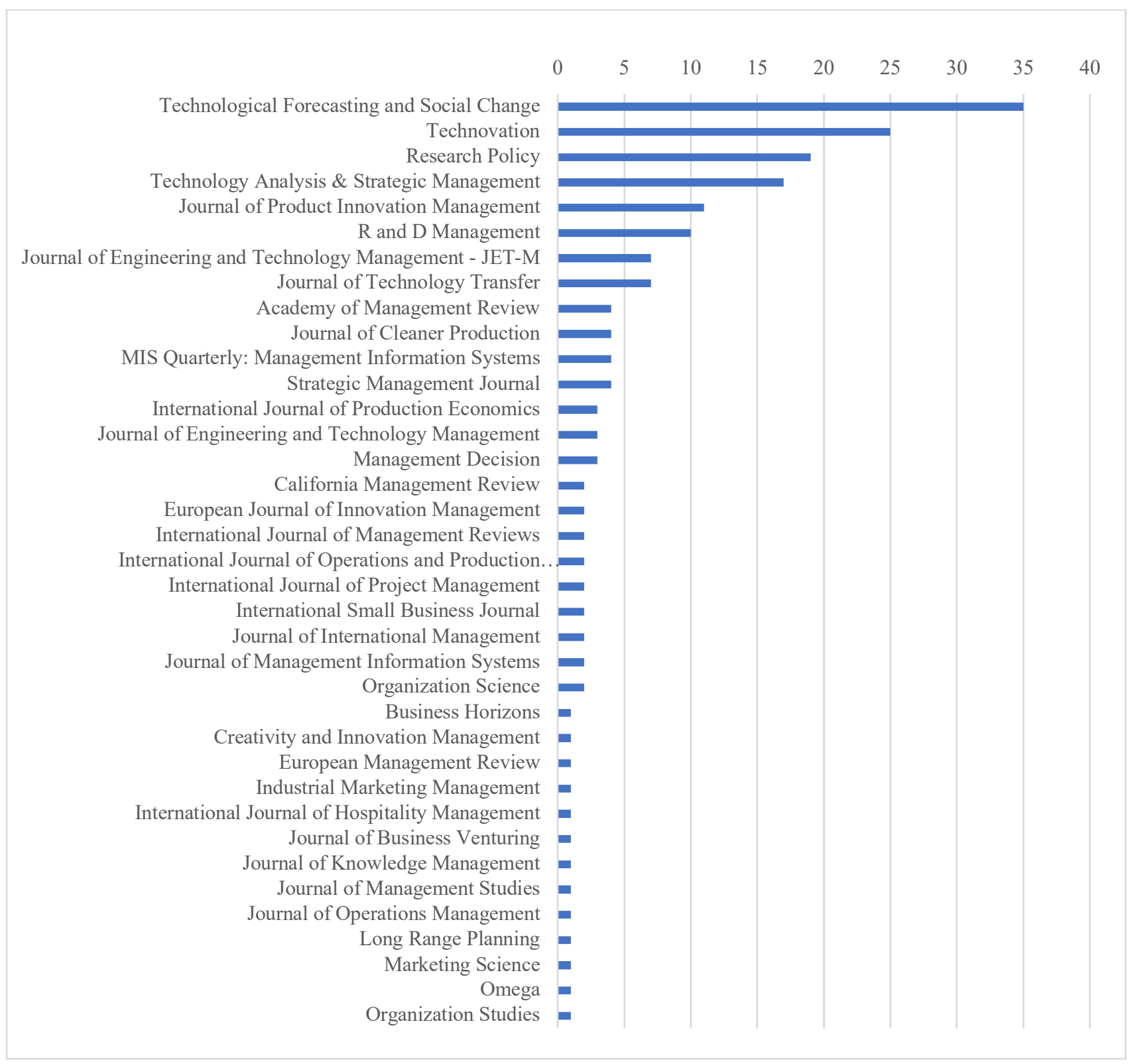

Fig. 2. Number of articles published in highly relevant journals.

\section{Findings emerging from the systematic literature review}

This section is dedicated to reviewing the 187 articles identified. In particular, we report the existing contributions on technology development (Inasiti, 2000; Klein and Kleinman 2002; Thomke, 2003; Govindarajan and Kopalle, 2006; Soukhoroukova et al., 2012) with the 
main aim of proposing an overview of the field focusing on the three main dimensions previously mentioned as relevant in this field: process, organization, and knowledge. In line with the seminal papers reported in the theoretical background, the 187 papers also show that these three dimensions are the most studied and highlighted categories in the investigated database. Thus, the findings that follow are organized per these three main dimensions.

\subsection{Process}

Scholars studying technologies and especially technology development have always focused on the crucial role of the different processes in fostering its advancement. Since Twiss (1992), studies in this literature stream have analyzed the linear sequence of phases guiding technology development (Högman and Johannesson, 2013). This linearity can reflect different elements, such as economic performance (Caerteling et al., 2008). Companies are more willing to invest in developing technologies that are more likely to have an impact on their future rather than their short-term revenues (Schmoch, 2007), thus requiring a structured process. Another crucial aspect that influences and triggers linear technology development is the set of competences and skills of the development team (Ghazinoory et al., 2017). Researchers show that multi-skilled and dynamic teams perform better at the fuzzy front end of technological innovation, as they are better able to manage uncertainty (Iansiti, 1995; Köhler and Som, 2014). Moreover, a driver reported as influencing development is user need (Garrety et al., 2004). Indeed, if development teams are able to identify a need to be fulfilled in the future life of customers, then the objective is set, and the process is driven accordingly (Jacobs et al., 2013). The academic papers also report processes that are not linear but iterative in view of several different factors. First, continuous customer involvement can cause strong iteration in the technology development process (Thomke, 2003). This is recognized as central in existing studies due to the fact that co-development with future customers can increase the probability of the success of a technology that is new and embodied in a product for the first time (Jha et 
al., 2017). This, of course, causes considerable iteration and non-linearity in the technology development process as a result of continuous changes in requirements and in customer needs. Similarly, scholars stress that iterations can increase the appropriability of technology from other players in the ecosystem (Leonardi et al., 2016). As a consequence of involving them in the process, communication, as well as management of the process, becomes more complicated, but different stakeholders can start gaining knowledge on the technology under development and can better appropriate and integrate it. Moreover, technology development can be influenced by the context in which the process takes place. The surrounding environment and the industry landscape can modify the linear process of initiation, internalization, and generation of new technology in a more iterative and recursive process where interactions with different players in the field are more frequent (Lee et al., 2011; Chang, 2017).

Scholars identify another interesting and relevant element at the process level in technology development, namely, the concept of alignment between functions and strategy (Lee et al., 2011). A formalized technology development process can undoubtedly align the entire organization in terms of the role of technology development for the future performance of the organization.

To conclude, the analysis of the papers in the process dimensions show a substantial difference in the process dynamics that can be framed in the gap between linear (Barnett and Clark, 1998) and iterative processes (Douthwaite et al., 2001; Schmoch, 2007). Indeed, extant researches emphasize the way the processes are managed and the order of the phases and actions taken to advance the development of technology.

\subsection{Organization}


The second area covered by the articles included in the study relates to the organization dimension. Differently from the process area focusing on the how, this focuses on the who. In this broad area, numerous investigations attempt to understand the involvement of different entities in technology development that can impact its advancement (Bogers et al., 2017).

Scholars highlight that acquisition from outside the company's boundaries can have negative effects on the differentiation aspects, but positive effects on the dynamic capabilities of employees (Swan and Allred, 2003). This view is in contrast with the open innovation paradigm (Chesbrough, 2006) and other investigations in the field stressing that looking outside the company and opening the process to external partners can secure long-term competitiveness (Chesbrough and Crowther, 2006; Sköld and Karlsson, 2012). Similarly, studies show that the number of interactions of the focal firm that develops a new technology with external players increases the likelihood of integrating and advancing the technology (Baughn and Osborne, 1989; Stock and Tatikonda, 2008). Conversely, other researchers show that the willingness to control the process and manage a pool of partners can justify higher investments and managing the process internally (Gama et al., 2017).

Moreover, at the network level, several researchers point out that the presence of different stakeholders involved in the process can have different effects on technology development. For example, governmental institutions, if involved in the process of crafting new technologies, can have a significant influence on the process itself (Caerteling et al., 2008). Furthermore, the policy aspects of technology development can influence both technology push and demand pull due to the fact that companies adapt their development to existing or future regulations (Costantini et al., 2015). On the contrary, other scholars report that universities do not influence and limit development, but their presence is often an enabling factor of developing more radical technological innovations (Verbeek et al., 2002; Hsu, 2005; Hayter, 2011). 
Moving on to the organization level, the team that develops the technology is deemed essential. For the technology to flourish during development, all those involved must understand the features developed, otherwise hampering the process (Garrety et al., 2004). Taylor (2010) proposes the opposite view, highlighting that team competition can positively affect the integration and development of the technology, as competition can unlock creativity and foster more radical innovations (Knaap et al., 2016). In addition, more efficient technology development requires multidisciplinary resources (Su and Moaniba, 2017), leveraging different capabilities to effectively transfer the technology into new products (Iansiti, 2000). As a consequence, technology development must not be considered as pertaining to only the R\&D department, since the more people are involved, the higher the probability of developing relevant technologies (Popp, 2017).

Although the different studies mentioned above in the organization dimension of technology development, from the in-depth analysis of the articles, seem emerging a common domain in the investigation on the organization dimension, the so-called multidisciplinarity. Indeed, even though the focus is the firm or the team involved in the technology development seems that the constant element is the fact that multidisciplinary skills at both the firm (Sköld and Karlsson, 2012) and at the individual level (Su and Moaniba, 2017) are required to perform this technological innovation.

\subsection{Knowledge}

The third dimension relevant to the technology development research field emerging from the review of the 187 papers is the knowledge. This dimension concerns the why question, completing the how and who of the two previous dimensions. Indeed, several scholars consider its role crucial in the process of managing the creation of new technology.

The first and most intuitive aspect relates to the risk of spillover. When companies are involved in a network of other players, they must learn how to absorb the technology and 
knowledge created, otherwise lowering and jeopardizing the value of being part of a network (Vanhaverbeke et al., 2015; Choi, 2017). Doing so requires having the technological knowledge to refer to, otherwise making it difficult to recognize the value and absorb the knowledge generated (Bidault and Fischer, 1994). This capability must evolve from acquiring knowledge to converting knowledge into actionable technology development management depending on the contextual variables that impact the company's ecosystem (Iansiti, 1995). In addition, companies must refresh their pool of knowledge, otherwise they will continuously focus on the same elements, thus reducing the probability of developing highly relevant new technologies (Johnson, 2011).

These findings show that the articles considered look quite intensively at different sources of knowledge within firms, but also from the outside perspective. Indeed, customers cannot fully accept new technologies if they do not have knowledge of their potential use (Rivard and Lapointe, 2012). Moreover, customer knowledge has been studied for the co-development of technologies. Scholars stress that technology users are untapped sources of knowledge creation (Nambisan et al., 1999), and their fresh minds and external perspectives can foster different knowledge in the technology development process.

The review of the articles in the knowledge area shows how the sources of knowledge can differ, considering the reason why they are involved in technology development. Thus, an interesting difference emerged between the designing perspective (Costantini et al., 2015) and the finding perspective (Technology Futures Analysis Methods Working Group, 2004; Dell'Era et al., 2017). The designing perspective is linked to the idea of embedding the technology developed in a new product to solve a problem by leveraging the knowledge that is already in the market. Differently, the finding perspective is related to the concept of exploring the opportunities of the technology and steering its development independently of 
the product. The latter perspective can only be achieved by recombining (Savino et al., 2017) or creating new knowledge at the technological level.

\section{Discussion and future directions}

This paper contributes to the technology management literature and especially the technology development stream by identifying four main approaches that are relevant to practitioners and scholars, enabling a better understanding of the field. By deeply analyzing the three dimensions of technology development previously reported in the results section (i.e., process, organization, and knowledge), the article shows how they can suggest different approaches to technology development. More specifically both the process and the knowledge dimensions highlight intriguing dichotomies that inspire alternative interpretation of the technology development; finally, the analysis of the organizational dimension shows as the technology development intensively leverages on multidisciplinary organizations. As a consequence, the framework proposed in the following paragraph relies on the dichotomies embedded in the process and knowledge dimensions.

\subsection{Technology Development: an emerging Framework}

Figure 3 illustrates four alternative approaches can be adopted in technology development in order to search for the right application. More precisely, we derive the four approaches from the dichotomies about the process and knowledge dimensions. Specifically, each quadrant provides a simple visualization of the four approaches to technology development. Emerging from the literature is that designing the right application usually prompts developers to direct their energy towards embedding the technology in a product in a linear or iterative approach, while finding the right application is usually driven by steering technology development itself. Considering this evidence and the fact that these two dimensions give rise to four intersections, we use this framework to develop the discussion and propose future research avenues. 


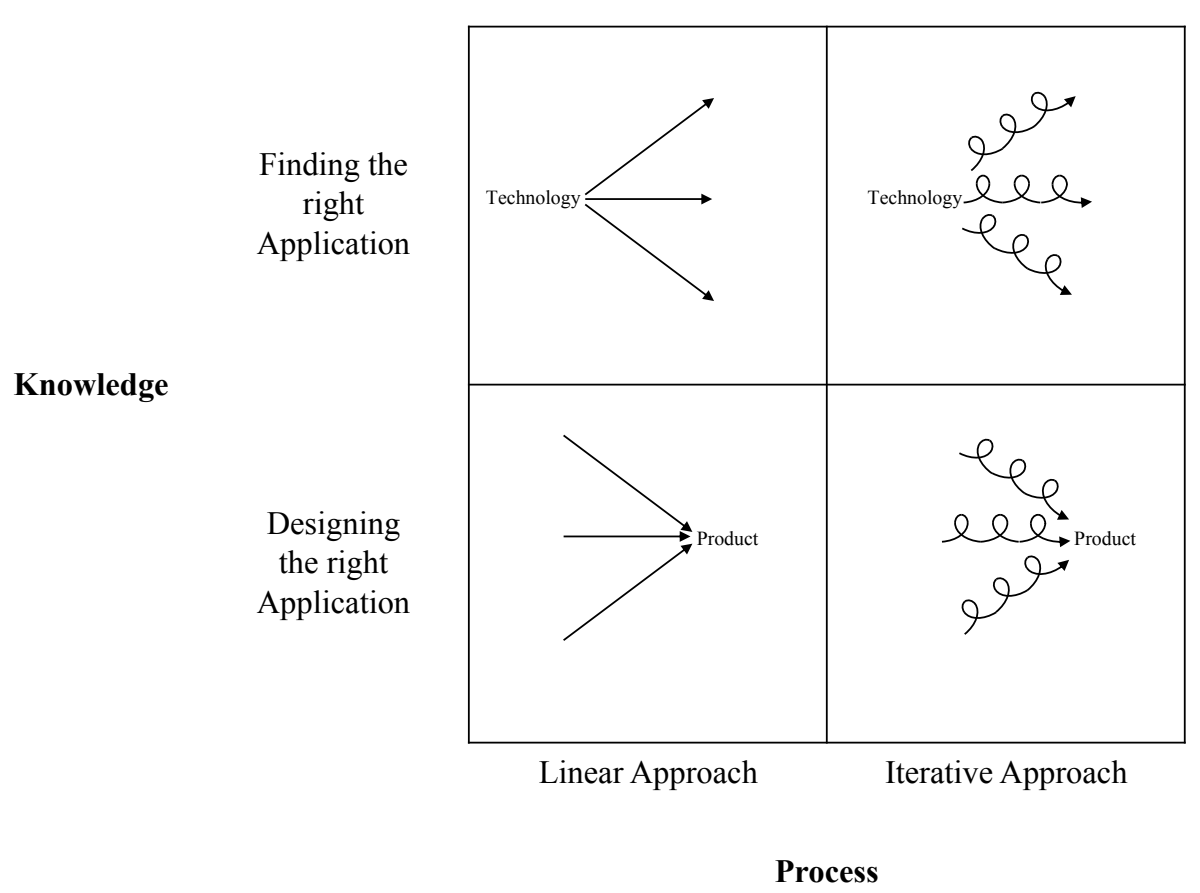

Fig. 3. Framework reporting the two dimensions in the technology development literature.

\subsection{Designing the right application in a linear approach}

The first approach is 'designing the right application' that embeds a new technology in a product using a linear development approach (Cooper, 1990; Phaal et al., 2004; Tomas GomezArias and Montermoso, 2007; Karlsson et al., 2010). The approaches schematizing and defining a sequence of stages and gates to develop better a technology to be integrated into a product contribute to this research stream (Cooper, 1990; Stolwijk et al., 2013). Studies in this vein point out that technology should be considered more as an enabler than a driver of the new product development process (Caerteling et al., 2008; Taylor, 2010). In line with this consideration, numerous studies focus on the role of customers and users in influencing the development path (Christensen and Rosenbloom, 1995; Tomas Gomez-Arias and Montermoso, 2007; Banerjee and Sharma, 2015).

The willingness to define a process with sequential phases is driven by the significant uncertainty that the development process entails (Karlsson et al., 2010). In addition, the contextual elements also play an important role in defining and influencing new product development based on new technology (Stock and Tatikonda, 2008). Researchers highlight the 
impact that society and politics can have on the sequential process oriented towards designing the right application for a technology (Suarez and Lanzolla, 2007; Costantini et al., 2015). As it is difficult to anticipate the potential impact of an emerging technology on business performance (Phaal et al., 2004), adopting a linear process that defines the phases of the activities to be performed in a product orientation facilitates the reduction of such uncertainty (Pillai et al., 2002; Gladysz and Kluczek, 2017). Finally, the findings show scarce attention to team composition for the efficient management of the process. Taylor (2010) emphasizes that competition can foster more radical new product development when technology is under development.

\subsubsection{The gaps and future research avenues}

The above cluster of studies describes the state-of-the-art of the theoretical discussion on the 'finding the right application' perspective and the linear approach. However, no insights are provided on how competition should be managed and how different business units should interact in the linear process. Similarly, another gap in the literature concerns the level of maturity of customers involved in the process. Scholars limit their contributions to the relevance of customer involvement and the benefit of co-development, without providing further explanations on the degree of expertise these end-users should have to foster technological development.

\subsection{Designing the right application in an iterative approach}

The linear approach is still valuable and recognized by scholars, even if attention is increasingly moving to the role of continuous iteration (Ries, 2011; Knaap et al., 2016). Emerging from reviewing the articles that adopt a 'designing the right application' perspective to technological development in an iterative approach is that traditional stage-gate is no longer the only option to manage this complex process (Cooper and Sommer, 2016), and that 
technology should be considered an enabler of new product development (Drejer and Riis, 1999; Xu et al., 2012). Indeed, the process is more iterative when technology is considered an enabler, as it is co-developed with the product, and thus characterized by several feedback loops (Jacobs et al., 2013). In this iterative process, scholars highlight that networks are not only a relevant and crucial aspect, but the roles of the different stakeholders in the network are also fundamental (Kirchberger and Pohl, 2016). Indeed, the organization that acts as a technology developer in the network should be multidisciplinary and structured in a different way to the firm that acquires the technology (Mohan and Rao, 2005), which is strongly linked to knowledge absorption (Grodal et al., 2015). Knowledge management in the iterative process is even more relevant when customers are involved in the process, and their selection is fundamental to guarantee the success of the new product developed (Tomas Gomez-Arias and Montermoso, 2007; Popp, 2017).

\subsubsection{The gaps and future research avenues}

Given the shift in focus from linear to iterative, the first relevant direction to explore is enriching the evidence that stresses the empirical value of the iterative approach by linking it to tangible improvements in performance. However, the impact of an iterative approach on the financial and economic aspects of designing a technological application is understudied in the current literature. In addition, there is a lack of knowledge on the optimal composition of organizations to foster better product innovation driven by high tech development. Finally, scholars should focus on customer involvement, which is empirically shown to be relevant in the knowledge absorption process, yet no statistical evidence is offered.

\subsection{Finding the right application in a linear approach}

Emerging from this review is that the linear approach is also studied when the focus is on finding the right application for a technology under development (Griffith, 1999; Hall et al., 
2014; Suzuki, 2015); in other words, when the knowledge created is absorbed by the firm that then searches the knowledge for the right applications (Magistretti et al., 2019).

When the orientation shifts from designing products to finding technology, the focus of the articles also shifts from the output of the development, such as a product, to its input, the embryonic technology (Song et al., 2014). Thus, if in the previous stream technology development is considered an enabler, in this stream, it is considered more a constraint due to the fact that it is the start of the project (Leten et al., 2016). As such, scholars mainly focus on the learning aspects of linear technology development (Kim, 1998; Ghazinoory et al., 2017).

Considering the knowledge dimension, firms must be organized to acquire knowledge and learn during the process, otherwise technology development may be hindered by a variety of factors (Su and Moaniba, 2017). This of course has a significant impact on the structure of the organization, which must adapt to facilitate communication around the new technology under development (Lee et al., 2011) this of course is facilitated by a multidisciplinary perspective. Moreover, to facilitate this process, scholars stress the importance of all those involved in the process of understanding the technology (Garrety et al., 2004). This aspect is even more relevant when the boundaries of the firm are expanded and the development of the technology follows a sequence of phases performed and influenced by others entities (Vanhaverbeke et al., 2015).

Scholars report that the process is more sequential and linear when an external network of firms is involved, since the inclusion of different entities favors the process due to a larger exploitable pool of knowledge (Stock and Tatikonda, 2008; Planko et al., 2016). In addition, these different sources usually know how to generate new knowledge. Such involvement has long been studied, and researchers highlight the role of networks of alliances on technology development. Specifically, working in networks increases the probability of learning from 
peers and better exploiting the knowledge generated (Baughn and Osborne, 1989; Nambisan et al., 1999).

\subsubsection{The gaps and future research avenues}

From the existing research on finding the right application in a linear approach, several gaps for future studies emerge. First, there is a lack of knowledge on the best time to involve external networks when the focus is on unveiling new breakthrough technologies. A further gap in the literature is on the role that end users can actually play in technology development when the focus is on adopting a linear process. Finally, more evidence on the benefits of adopting a linear approach when technological development uncertainty is high could make this literature even more relevant for suppliers of advanced technologies.

\subsection{Finding the right application in an iterative approach}

The last quadrant of Fig. 3 results from combining the iterative approach to process management and finding the right technological application in relation to the knowledge dimensions.

In a world where the issue is no longer having ideas but unveiling the opportunities offered by technologies (Chesbrough, 2003; Verganti, 2011; Dell'Era et al., 2017), a more crafted process that adequately supports technology development is fundamental. In this vein, scholars in the last decades have focused on better integration of the stage-gate approach with a more iterative approach to facilitate the transfer and integration of technology (Linton and Walsh, 2008). Undoubtedly, more flexible processes enabling better integration amongst the parties would reduce uncertainty, as people can adapt their process more rapidly in reaction to the changing and evolving context (Adler, 1988; Högman and Johannesson, 2013; Magistretti and Dell'Era, 2019). Uncertainty can also be reduced by focusing on different adoption scenarios 
for the technology. This would increase the opportunities considered and the probability of obtaining a breakthrough technology (Sköld and Karlsson, 2012).

The iterative aspect is stressed by the exploration and exploitation of complementarity (Zhang et al., 2017). The iteration between exploration and exploitation is frequently influenced by different success and performance factors that are important for technology developers (Kim and Lee, 2003). Previous studies underline the positive impact in this iterative process of identifying a technology champion, technology development experts and promoters (Chaudhuri, 1986). These are crucial for the efficient management of iterative technology development, as they are always part of the learning-by-doing process (Slaughter, 1993).

The previous sections reported the existing debate on the process and organization dimensions, while in the remainder we will focus on the other relevant dimension: knowledge.

When iteration is put in place, knowledge generation can be particularly complex, and the internal resources must therefore be well trained and skilled to continuously absorb the insights generated (Bidault and Fischer, 1994). This is the reason that suggested researchers in pointing out the key role that end users might have in this iterative development (Leonardi, 2012; Rivard and Lapointe, 2012; Lehoux et al., 2014; Gama et al., 2017).

\subsubsection{The gaps and future research avenues}

The previously reported cluster of studies show the state-of-the-art of the literature on the finding and iterative technology development approaches. In view of the complexity of technology development, more investigations on how the iterative approach reduces the uncertainty of outcomes would generate additional value for scholars and practitioners. Moreover, further studies on when in the overall iterative process such as end user involvement should take place, and how this interaction between companies and users should be managed, would enrich knowledge in the field. Second, further insights on how to unveil quiescent 
meanings in technologies would foster the willingness to invest in R\&D for high technology companies.

\subsection{Current and Future avenues of research in the Technology Development framework}

The previous sections report the four main clusters emerging from the combination of the process, and knowledge dimensions that led to the creation of the four quadrants discussed in

\begin{tabular}{|c|c|c|c|}
\hline \multirow{3}{*}{ Knowledge } & $\begin{array}{l}\text { Finding the } \\
\text { right } \\
\text { Application }\end{array}$ & $\begin{array}{l}\text { 1. Baughn and Osborne, } 1989 \\
\text { 2. Kim, } 1998 \\
\text { 3. Griffith, } 1999 \\
\text { 4. Nambisan et al., } 1999 \\
\text { 5. Stock and Tatikonda, } 2008 \\
\text { 6. Lee et al., 2011 } \\
\text { 7. Song et al,., 2014 } \\
\text { 8. Suzuki, 2015 } \\
\text { 9. Leten et al., 2016 } \\
\text { 10. Ghazinoory et al., } 2017\end{array}$ & $\begin{array}{ll}\text { 1. } & \text { Chaudhuri, } 1986 \\
\text { 2. } & \text { Adler, } 1988 \\
\text { 3. } & \text { Slaughter, } 1993 \\
\text { 4. } & \text { Adner, 202 } \\
\text { 5. } & \text { Kim and Lee, 2003 } \\
\text { 6. } & \text { Narula, 2004 } \\
\text { 7. } & \text { Leonardi, 2013 } \\
\text { 8. } & \text { Soöld and Karlsson, } 2012 \\
\text { 9. } & \text { Lehoux et al., 2014 } \\
\text { 10. } & \text { Zhang et al., 2017 }\end{array}$ \\
\hline & $\begin{array}{l}\text { Designing } \\
\text { the right } \\
\text { Application }\end{array}$ & $\begin{array}{l}\text { 1. Griffith, } 1999 \\
\text { 2. Pillali et al,, } 2002 \\
\text { 3. Phaal, } 2004 \\
\text { 4. Tomas Gomez-Arias and Montermoso, } \\
2007 \\
\text { 5. Suarez and Lanzolla, } 2007 \\
\text { 6. Caerteling et al, } 2008 \\
\text { 7. Taylor, } 2010 \\
\text { 8. Stolwijk et al, } 2013 \\
\text { 9. Costantini et al., } 2015 \\
\text { 10. Gladysz and Kluczek, } 2017\end{array}$ & $\begin{array}{l}\text { 1. Robertson and Gatignon, } 1998 \\
\text { 2. Drejer and Riis, } 1999 \\
\text { 3. Mohan and Ra, } 2005 \\
\text { 4. Chung and Wee, 2008 } \\
\text { 5. Xu et al., 2012 } \\
\text { 6. Jacobs et al., } 2013 \\
\text { 7. Grodal et al., 2015 } \\
\text { 8. Kirchberger and Pohl, } 2016 \\
\text { 9. Knaap et al., 2016 } \\
\text { 10. Popp, 2017 }\end{array}$ \\
\hline & & Linear Approach & Iterative Approach \\
\hline
\end{tabular}

terms of contributions and future research avenues. Fig. 4 provides a snapshot of the ten key references identified as the most relevant in each cluster to understand the evolution of the discussion in each of the four areas.

Fig. 4. Snapshot of the current theoretical debates in the technology development field

Fig. 5 summarizes the main gaps emerging from the review by positioning these in the previously reported framework (Fig. 3). This is a crucial step in setting the agenda for future studies as it both maps and interprets the current view on technology development, and helps future scholars understand the relevant areas and dimensions to address. Particularly evident is that the technology development field could be further investigated in relation to designing and 
finding the right application, as well as the linear and iterative approaches. This systematic literature review therefore shows that scholars should focus on the process dimensions, as well as on the knowledge dimension, to enhance the understanding of practitioners and academics on the development processes. Moreover, a closer look could be given to the organizational dimension to clarify better if the single perspective (i.e., multidisciplinary) detected in this systematic review is valid in every context or not. Empirical studies can unveil hidden dichotomies relevant inside the organizational dimension and helps in enlarging the perspective by adding to the framework a tridimensional view.

\begin{tabular}{|c|c|c|c|}
\hline \multirow{4}{*}{ Knowledge } & $\begin{array}{l}\text { Finding the } \\
\text { right } \\
\text { Application }\end{array}$ & $\begin{array}{l}\text { When and how should external } \\
\text { partners or collaborators be } \\
\text { involved in the process? } \\
\text { What is the role of the final } \\
\text { customer in finding the right } \\
\text { application? } \\
\text { What are the pros and cons of } \\
\text { linearity in finding the right } \\
\text { application? }\end{array}$ & $\begin{array}{l}\text { - When and how should users be } \\
\text { involved in testing the technology } \\
\text { developed? } \\
\text { - How can an iterative approach } \\
\text { reduce uncertainty in finding the } \\
\text { right application for technologies? } \\
\text { How can companies unveil the } \\
\text { quiescent meaning in } \\
\text { technologies? }\end{array}$ \\
\hline & & & \\
\hline & $\begin{array}{l}\text { Designing } \\
\text { the right } \\
\text { Application }\end{array}$ & $\begin{array}{l}\text { How can companies manage team } \\
\text { competition in the technology } \\
\text { development processes? } \\
\text { - How should different business } \\
\text { units interact in the linear } \\
\text { approach? } \\
\text { What are the underpinning } \\
\text { characteristics of customers that } \\
\text { should be involved in the process? }\end{array}$ & $\begin{array}{l}\text { What are the positive impacts on } \\
\text { performance when the company } \\
\text { adopts an iterative approach? } \\
\text { How should the company be } \\
\text { organized to increase the } \\
\text { probability of designing the right } \\
\text { application for a technology? } \\
\text { How can digital technologies } \\
\text { impact the design of new } \\
\text { applications? }\end{array}$ \\
\hline & & \multicolumn{2}{|r|}{ Iterative Approach } \\
\hline
\end{tabular}

Fig. 5. Summary of research gaps emerging from the literature review.

\section{Conclusions}

To conclude, this study contributes to the ongoing debate on technology development in three main areas. First, it sheds light on the current evolution of research in the field of technology development by identifying the three main dimensions investigated in the published articles (process, organization, and knowledge), fundamental elements that scholars and practitioners should consider when dealing with technology development. Indeed, there cannot 
be technology development without a process, without multidisciplinary within an organization, or without managing different sources of knowledge. This is a first contribution that can help the technology management field deal better with the complexity of creating technological innovations. Second, the current review enriches knowledge in the field of technology development by proposing that searching for the right application should be guided by understanding the four approaches that companies and scholars adopt, and the ways in which the right application of a technology can be searched. This aspect is certainly relevant for practitioners looking at different approaches to efficiently and effectively manage technology development projects. Third, questions remain and the twelve future research avenues (Fig. 5) proposed, indicate that this field is still under development. The substantial literature available on technology development is, of course, useful, but the world is evolving, and so must the research.

\section{References}

Adler, P.S., 1988. Managing flexible automation. California Management Review 30 (3), 3456.

Adner, R., Kapoor, R., 2016. Innovation ecosystems and the pace of substitution: re-examining technology S-curves. Strategic Management Journal 37 (4), 625-648.

Adner, R., Levinthal, D., 2001. Demand heterogeneity and technology evolution: implications for product and process innovation. Management Science 47 (5), 611-628.

Akgün, A.E., Keskin, H., Byrne, J.C., Aren, S., 2007. Emotional and learning capability and their impact on product innovativeness and firm performance. Technovation 27 (9), 501513.

Arbesman, S., 2016. Overcomplicated: technology at the limits of comprehension. Penguin.

Ardito, L., Messeni Petruzzelli, A., Albino, V., 2015. From technological inventions to new products: A systematic review and research agenda of the main enabling factors. European Management Review 12, 113-147.

Armstrong, J.S., 2001. Principles of forecasting: a handbook for researchers and practitioners (Vol. 30). Springer Science \& Business Media.

Banerjee, S., Sharma, A.K., 2015. Co-creation as a risk-sharing strategy for the development of innovative EUV lithography technology in the semiconductor industry. Technology Analysis \& Strategic Management 27 (9), 1097-1113. 
Barczak, G., Griffin, A., Kahn, K.B., 2009. Perspective: trends and drivers of success in NPD practices: results of the 2003 PDMA best practices study. Journal of Product Innovation Management 26 (1), 3-23.

Barnett, B.D., Clark, K.B., 1998. Problem solving in product development: a model for the advanced materials industries. International Journal of Technology Management 15 (8), 805-820.

Baughn, C.C., Osborne, R.N., 1989. Strategies for successful technological development. The Journal of Technology Transfer 14 (3-4), 5-13.

Bidault, F., Fischer, W.A., 1994. Technology transactions: networks over markets. $R \& D$ Management 24 (4), 373-386.

Bogers, M., Zobel, A.K., Afuah, A., Almirall, E., Brunswicker, S., Dahlander, L., Frederiksen, L., Gawer, A., Gruber, M., Haefliger, S., Hagedoorn, J., 2017. The open innovation research landscape: established perspectives and emerging themes across different levels of analysis. Industry and Innovation 24 (1), 8-40.

Boon, W.P., Moors, E.H., Kuhlmann, S., Smits, R.E., 2008. Demand articulation in intermediary organisations: the case of orphan drugs in the Netherlands. Technological Forecasting and Social Change 75 (5), 644-671.

Brown, T., 2008. Design thinking. Harvard Business Review 86 (6), 84-94.

Buganza, T., Dell'Era, C., Pellizzoni, E., Trabucchi, D., Verganti, R., 2015. Unveiling the potentialities provided by new technologies: A process to pursue technology epiphanies in the smartphone app industry. Creativity and Innovation Management 24 (3), 391-414.

Caerteling, J.S., Halman, J.I., Doree, A.G., 2008. Technology commercialization in road infrastructure: how government affects the variation and appropriability of technology. Journal of Product Innovation Management 25 (2), 143-161.

Calof, J., Smith, J., 2010. The integrative domain of foresight and competitive intelligence and its impact on R\&D management. $R \& D$ Management 40 (1), 31-39.

Chang, S. H., 2017. The technology networks and development trends of university-industry collaborative patents. Technological Forecasting and Social Change 118, 107-113.

Chaudhuri, S., 1986. Technological innovation in a research laboratory in India: a case study. Research Policy 15 (2), 89-103.

Chesbrough, H., 2003. The governance and performance of Xerox's technology spin-off companies. Research Policy 32 (3), 403-421.

Chesbrough, H., 2006. Open innovation: the new imperative for creating and profiting from technology. Harvard Business Press.

Chesbrough, H., Crowther, A.K., 2006. Beyond high tech: early adopters of open innovation in other industries. $R \& D$ Management 36 (3), 229-236.

Choi, H., 2017. Ready-steady-go for emerging technologies in post catch-up countries: a longitudinal network analysis of nanotech in Korea. Technology Analysis \& Strategic Management 29 (8), 946-959.

Christensen, C.M., Rosenbloom, R.S., 1995. Explaining the attacker's advantage: technological paradigms, organizational dynamics, and the value network. Research Policy 24 (2), 233257.

Cooper, R.G., 1990. Stage-gate systems: a new tool for managing new products. Business Horizons 33 (3), 44-54.

Cooper, R.G., 1994. Perspective third-generation new product processes. Journal of Product Innovation Management 11 (1), 3-14. 
Cooper, R.G., 2006. Managing technology development projects. Research-Technology Management, 49 (6), 23-31.

Cooper, R.G., Kleinschmidt, E.J., 1986. An investigation into the new product process: steps, deficiencies, and impact. Journal of Product Innovation Management 3 (2), 71-85.

Cooper, R.G., Sommer, A.F., 2016. The Agile-Stage-Gate hybrid model: a promising new approach and a new research opportunity. Journal of Product Innovation Management 33 (5), 513-526.

Costantini, V., Crespi, F., Martini, C., Pennacchio, L., 2015. Demand-pull and technologypush public support for eco-innovation: the case of the biofuels sector. Research Policy 44 (3), 577-595.

Cuhls, K., 2003. From forecasting to foresight processes: new participative foresight activities in Germany. Journal of Forecasting 22 (2-3), 93-111.

Dahlin, K.B., Behrens, D.M., 2005. When is an invention really radical? Defining and measuring technological radicalness. Research Policy 34 (5), 717-737.

Danneels, E., 2007. The process of technological competence leveraging. Strategic Management Journal 28 (5), 511-533.

Danneels, E., Frattini, F., 2018. Finding applications for technologies beyond the core business. MIT Sloan.

Dell'Era, C., Altuna, N., Magistretti, S., Verganti, R., 2017. Discovering quiescent meanings in technologies: exploring the design management practices that support the development of technology epiphanies. Technology Analysis \& Strategic Management 29 (2), 149-166.

Denicolai, S., Ramirez, M., Tidd, J., 2016. Overcoming the false dichotomy between internal $\mathrm{R} \& \mathrm{D}$ and external knowledge acquisition: absorptive capacity dynamics over time. Technological Forecasting and Social Change 104, 57-65.

Douthwaite, B., Keatinge, J.D.H., Park, J.R., 2001. Why promising technologies fail: the neglected role of user innovation during adoption. Research Policy 30 (5), 819-836.

Dreborg, K.H., 1996. Essence of backcasting. Futures 28 (9), 813-828.

Drejer, A., Riis, J.O., 1999. Competence development and technology: how learning and technology can be meaningfully integrated. Technovation 19 (10), 631-644.

Eto, H., 2003. The suitability of technology forecasting/foresight methods for decision systems and strategy: a Japanese view. Technological Forecasting and Social Change 70 (3), 231249.

Fleming, L., 2001. Recombinant uncertainty in technological search. Management Science 47 (1), 117-132.

Gama, F., Sjödin, D.R., Frishammar, J., 2017. Managing interorganizational technology development: project management practices for market- and science-based partnerships. Creativity and Innovation Management 26 (2), 115-127.

Gambardella, A., McGahan, A.M., 2010. Business-model innovation: general purpose technologies and their implications for industry structure. Long Range Planning 43 (2-3), 262-271.

Garrety, K., Robertson, P.L., Badham, R., 2004. Integrating communities of practice in technology development projects. International Journal of Project Management 22 (5), $351-358$.

Ghazinoory, S., Dastranj, N., Saghafi, F., Kulshreshtha, A., Hasanzadeh, A., 2017. Technology roadmapping architecture based on technological learning: case study of social banking in Iran. Technological Forecasting and Social Change 122, 231-242. 
Gladysz, B., Kluczek, A., 2017. A framework for strategic assessment of far-reaching technologies: a case study of Combined Heat and Power technology. Journal of Cleaner Production 167, 242-252.

Govindarajan, V., Kopalle, P.K., 2006. The usefulness of measuring disruptiveness of innovations ex post in making ex ante predictions. Journal of Product Innovation Management 23 (1), 12-18.

Griffin, A., 1997. PDMA research on new product development practices: updating trends and benchmarking best practices. Journal of Product Innovation Management 14 (6), 429-458.

Griffith, T.L., 1999. Technology features as triggers for sensemaking. Academy of Management Review 24 (3), 472-488.

Grodal, S., Gotsopoulos, A., Suarez, F.F., 2015. The coevolution of technologies and categories during industry emergence. Academy of Management Review 40 (3), 423-445.

Hall, J., Bachor, V., Matos, S., 2014. Developing and diffusing new technologies: strategies for legitimization. California Management Review 56 (3), 98-117.

Hayter, C.S., 2011. In search of the profit-maximizing actor: motivations and definitions of success from nascent academic entrepreneurs. The Journal of Technology Transfer 36 (3), $340-352$.

Hegger, D.L., Van Vliet, J., Van Vliet, B.J., 2007. Niche management and its contribution to regime change: the case of innovation in sanitation. Technology Analysis \& Strategic Management 19 (6), 729-746.

Högman, U., Johannesson, H., 2013. Applying stage-gate processes to technology development: experience from six hardware-oriented companies. Journal of Engineering and Technology Management 30 (3), 264-287.

Hsu, C.W., 2005. Formation of industrial innovation mechanisms through the research institute. Technovation 25 (11), 1317-1329.

Iansiti, M., 1995. Technology integration: managing technological evolution in a complex environment. Research Policy 24 (4), 521-542.

Iansiti, M., 2000. How the incumbent can win: managing technological transitions in the semiconductor industry. Management Science 46 (2), 169-185.

Jacobs, C.D., Steyaert, C., Ueberbacher, F., 2013. Anticipating intended users: prospective sensemaking in technology development. Technology Analysis \& Strategic Management 25 (9), 1027-1043.

Jha, A., Fernandes, K., Xiong, Y., Nie, J., Agarwal, N., Tiwari, M.K., 2017. Effects of demand forecast and resource sharing on collaborative new product development in supply chain. International Journal of Production Economics 193, 207-221.

Johnson, W.H., 2011. Managing university technology development using organizational control theory. Research Policy 40 (6), 842-852.

Kahn, H., 1992. Technology forecasting for decision-making. In Twiss, B., Managing Technological Innovation, Pearson Education, pp. 258-286.

Kahn, K.B., 2002. An exploratory investigation of new product forecasting practices. Journal of Product Innovation Management 19 (2), 133-143.

Kaplan, A.W., 1999. From passive to active about solar electricity: innovation decision process and photovoltaic interest generation. Technovation 19 (8), 467-481.

Karlsson, C., Taylor, M., Taylor, A., 2010. Integrating new technology in established organizations: a mapping of integration mechanisms. International Journal of Operations \& Production Management 30 (7), 672-699. 
Keupp, M.M., Palmié, M., Gassmann, O., 2012. The strategic management of innovation: a systematic review and paths for future research. International Journal of Management Reviews 14 (4), 367-390.

Kim, B., 1998. Optimal development of production technology when autonomous and induced learning are present. International Journal of Production Economics 55 (1), 39-52.

Kim, Y., Lee, K., 2003. Technological collaboration in the Korean electronic parts industry: patterns and key success factors. R\&D Management 33 (1), 59-77.

Kirchberger, M.A., Pohl, L., 2016. Technology commercialization: a literature review of success factors and antecedents across different contexts. The Journal of Technology Transfer 41 (5), 1077-1112.

Klein, H.K., Kleinman, D.L., 2002. The social construction of technology: structural considerations. Science, Technology \& Human Values 27 (1), 28-52.

Knapp, J., Zeratsky, J., Kowitz, B., 2016. Sprint: how to solve big problems and test new ideas in just five days. Simon and Schuster.

Köhler, A.R., Som, C., 2014. Risk preventative innovation strategies for emerging technologies the cases of nano-textiles and smart textiles. Technovation 34 (8), 420-430.

Krishnan, V., Bhattacharya, S., 2002. Technology selection and commitment in new product development: the role of uncertainty and design flexibility. Management Science 48 (3), 313-327.

Lee, J.H., Phaal, R., Lee, C., 2011. An empirical analysis of the determinants of technology roadmap utilization. $R \& D$ Management 41 (5), 485-508.

Lehoux, P., Daudelin, G., Williams-Jones, B., Denis, J. L., Longo, C., 2014. How do business model and health technology design influence each other? Insights from a longitudinal case study of three academic spin-offs. Research Policy 43 (6), 1025-1038.

Leonardi, P.M., 2008. Indeterminacy and the discourse of inevitability in international technology management. Academy of Management Review 33 (4), 975-984.

Leonardi, P.M., 2012. When does technology use enable network change in organizations? A comparative study of feature use and shared affordances. MIS Quarterly 37 (3), 749-775.

Leonardi, P.M., Bailey, D.E., Diniz, E.H., Sholler, D., Nardi, B.A., 2016. Multiplex appropriation in complex systems implementation: the case of Brazil's correspondent banking system. MIS Quarterly 40 (2), 461-473.

Leten, B., Belderbos, R., Looy, B.V., 2016. Entry and technological performance in new technology domains: technological opportunities, technology competition and technological relatedness. Journal of Management Studies 53 (8), 1257-1291.

Linstone, H.A., 2011. Three eras of technology foresight. Technovation 31 (2), 69-76.

Linton, J.D., Walsh, S.T., 2008. Acceleration and extension of opportunity recognition for nanotechnologies and other emerging technologies. International Small Business Journal 26 (1), 83-99.

Magistretti, S., Dell'Era, C., 2019. Unveiling opportunities afforded by emerging technologies: evidences from the drone industry. Technology Analysis \& Strategic Management 31 (5), 606-623.

Magistretti, S., Dell'Era, C., De Massis, A., \& Frattini, F. (2019). Exploring the relationship between types of family involvement and collaborative innovation in design-intensive firms: insights from two leading players in the furniture industry. Industry and Innovation, $1-31$. 
Magistretti, S., Trabucchi, D., Dell'Era, C., Buganza, T. 2019. A New Path Toward a Hybrid Model: Insights from PwC's Italian Experience Centre. Research-Technology Management, 62(5), 30-37.

Markman, G.D., Gianiodis, P.T., Phan, P.H., Balkin, D.B., 2005. Innovation speed: transferring university technology to market. Research Policy 34 (7), 1058-1075.

Meier, M., 2011. Knowledge management in strategic alliances: a review of empirical evidence. International Journal of Management Reviews, 13, 1-23.

Mohan, S.R., Rao, A.R., 2005. Strategy for technology development in public R\&D institutes by partnering with the industry. Technovation 25 (12), 1484-1491.

Nambisan, S. 2017. Digital entrepreneurship: toward a digital technology perspective of entrepreneurship. Entrepreneurship Theory and Practice 41 (6), 1029-1055.

Nambisan, S., Agarwal, R., Tanniru, M., 1999. Organizational mechanisms for enhancing user innovation in information technology. MIS Quarterly, 365-395.

Nambisan, S., Lyytinen, K., Majchrzak, A., Song, M. 2017. Digital Innovation Management: Reinventing innovation management research in a digital world. MIS Quarterly 41(1).

Ordanini, A., Rubera, G., DeFillippi, R., 2008. The many moods of inter-organizational imitation: a critical review. International Journal of Management Reviews 10, 375-398.

Parasuraman, A., 2000. Technology Readiness Index (TRI) a multiple-item scale to measure readiness to embrace new technologies. Journal of Service Research 2 (4), 307-320.

Petruzzelli, A.M., 2011. The impact of technological relatedness, prior ties, and geographical distance on university-industry collaborations: a joint-patent analysis. Technovation 31 (7), 309-319.

Phaal, R., Farrukh, C.J., Probert, D.R., 2004. Technology roadmapping: a planning framework for evolution and revolution. Technological Forecasting and Social Change 71 (1-2), 526.

Pillai, A.S., Joshi, A., Rao, K.S., 2002. Performance measurement of R\&D projects in a multiproject, concurrent engineering environment. International Journal of Project Management 20 (2), 165-177.

Pittaway, L., Robertson, M., Munir, K., Denyer, D. Neely, A., 2004. Networking and innovation: a systematic review of the evidence. International Journal of Management Reviews 5, 137-168.

Planko, J., Cramer, J.M., Chappin, M. M., Hekkert, M. P., 2016. Strategic collective system building to commercialize sustainability innovations. Journal of Cleaner Production 112, 2328-2341.

Podsakoff, P., MacKenzie, S., Bachrach, D. Podsakoff, N., 2005. The influence of management journals in the 1980s and 1990s. Strategic Management Journal 26, 473-488.

Popp, D., 2017. From science to technology: the value of knowledge from different energy research institutions. Research Policy 46 (9), 1580-1594.

Proni, G., Carimati, P., 2007. Leggere le tendenze. Nuovi Percorsi di ricerca per il marketing. Lupetti: Milano.

Rashman, L., Withers, E., Hartley, J., 2009. Organizational learning and knowledge in public service organizations: a systematic review of the literature. International Journal of Management Reviews 11, 463-494.

Reger, G., 2001. Technology foresight in companies: from an indicator to a network and process perspective. Technology Analysis \& Strategic Management 13 (4), 533-553. 
Ries, E., 2011. The lean startup: how today's entrepreneurs use continuous innovation to create radically successful businesses. Crown Business.

Rivard, S., Lapointe, L., 2012. Information technology implementers' responses to user resistance: nature and effects. MIS Quarterly, 897-920.

Sakkab, N.Y., 2002. Connect \& develop complements research \& develop at P\&G. ResearchTechnology Management 45 (2), 38-45.

Savino, T., Messeni Petruzzelli, A., Albino, V., 2017. Search and recombination process to innovate: a review of the empirical evidence and a research agenda. International Journal of Management Reviews 19 (1), 54-75.

Scapolo, F., Porter, A. L., 2008. New methodological developments in FTA. In Future-oriented technology analysis (pp. 149-162). Springer Berlin Heidelberg.

Schilling, M. A. 2002. Technology success and failure in winner-take-all markets: The impact of learning orientation, timing, and network externalities. Academy of Management Journal, 45(2), 387-398.

Schmoch, U., 2007. Double-boom cycles and the comeback of science-push and marketpull. Research Policy 36 (7), 1000-1015.

Sköld, M., Karlsson, C., 2012. Technology sharing in manufacturing business groups. Journal of Product Innovation Management 29 (1), 113-124.

Slaughter, S., 1993. Innovation and learning during implementation: a comparison of user and manufacturer innovations. Research Policy 22 (1), 81-95.

Song, M., Hooshangi, S., Zhao, Y.L., Halman, J.I., 2014. How does technological regime affect performance of technology development projects? Journal of Product Innovation Management 31 (S1), 60-74.

Soukhoroukova, A., Spann, M., Skiera, B., 2012. Sourcing, filtering, and evaluating new product ideas: an empirical exploration of the performance of idea markets. Journal of Product Innovation Management, 29(1), 100-112.

Stock, G.N., Tatikonda, M.V., 2008. The joint influence of technology uncertainty and interorganizational interaction on external technology integration success. Journal of Operations Management 26 (1), 65-80.

Stolwijk, C.C.M., Ortt, J.R., Den Hartigh, E., 2013. The joint evolution of alliance networks and technology: a survey of the empirical literature. Technological Forecasting and Social Change 80 (7), 1287-1305.

Su, H.N., Moaniba, I.M., 2017. Investigating the dynamics of interdisciplinary evolution in technology developments. Technological Forecasting and Social Change 122, 12-23.

Suarez, F.F., Lanzolla, G., 2007. The role of environmental dynamics in building a first mover advantage theory. Academy of Management Review 32 (2), 377-392.

Suzuki, M., 2015. Identifying roles of international institutions in clean energy technology innovation and diffusion in the developing countries: matching barriers with roles of the institutions. Journal of Cleaner Production 98, 229-240.

Swan, K.S., Allred, B.B., 2003. A product and process model of the technology-sourcing decision. Journal of Product Innovation Management 20 (6), 485-496.

Taylor, A., 2010. The next generation: technology adoption and integration through internal competition in new product development. Organization Science 21 (1), 23-41.

Technology Futures Analysis Methods Working Group, 2004. Technology futures analysis: toward integration of the field and new methods. Technological Forecasting and Social Change 71 (3), 287-303. 
Thomke, S., 2001. Enlightened experimentation. The new imperative for innovation. Harvard Business Review 79 (2), 66-75.

Thomke, S.H., 2003. Experimentation matters: unlocking the potential of new technologies for innovation. Harvard Business Press.

Tomas Gomez-Arias, J., Montermoso, J.P., 2007. Initial reference customer selection for high technology products. Management Decision 45 (6), 982-990.

Tranfield, D., Denyer, D., Smart, P., 2003. Towards a methodology for developing evidenceinformed management knowledge by means of systematic review. British Journal of Management 14 (3), 207-222.

Twiss, B.C., 1992. Managing technological innovation (Vol. 321). London: Pitman.

Van de Vrande, V., Vanhaverbeke, W., Duysters, G., 2011. Technology in-sourcing and the creation of pioneering technologies. Journal of Product Innovation Management 28 (6), 974-987.

Vanhaverbeke, W., Belderbos, R., Duysters, G., Beerkens, B., 2015. Technological performance and alliances over the industry life cycle: evidence from the ASIC industry. Journal of Product Innovation Management 32 (4), 556-573.

Vanhaverbeke, W., Du, J., Leten, B., Aalders, F., 2014. Exploring open innovation at the level of R\&D projects. In H. Chesbrough, W. Vanhaverbeke, J. West (eds.), New frontiers in open innovation (pp. 115-131). Oxford: Oxford University Press.

Verbeek, A., Debackere, K., Luwel, M., Zimmermann, E., 2002. Measuring progress and evolution in science and technology-I: the multiple uses of bibliometric indicators. International Journal of Management Reviews 4 (2), 179-211.

Verganti, R., 2009. Design-driven innovation, changing the rules of competition by radically innovating what things mean, Harvard Business Press.

Verganti, R., 2011. Radical design and technology epiphanies: a new focus for research on design management. Journal of Product Innovation Management 28 (3), 384-388.

Verganti, R., 2017. Overcrowded: designing meaningful products in a world awash with Ideas. MIT Press.

Wang, C.L., Chugh, H., 2014. Entrepreneurial learning: past research and future challenges. International Journal of Management Reviews 16, 24-61.

Wang, I.K., Seidle, R., 2017. The degree of technological innovation: a demand heterogeneity perspective. Technological Forecasting and Social Change 125, 166-177.

Weng, C.S., Yang, W.G., Lai, K.K., 2014. Technological position in alliances network. Technology Analysis \& Strategic Management 26 (6), 669-685.

Xu, K., Huang, K.F., Gao, S., 2012. Technology sourcing, appropriability regimes, and new product development. Journal of Engineering and Technology Management 29 (2), 265280.

Zhang, F., Wang, Y., Li, D., Cui, V., 2017. Configurations of innovations across domains: an organizational ambidexterity view. Journal of Product Innovation Management 34 (6), 821-841. 
Appendix

\begin{tabular}{|c|c|c|c|c|c|c|c|}
\hline Authors & Title & Year & Journal & Citations & \begin{tabular}{|c|} 
Process \\
$(\mathrm{P})$
\end{tabular} & $\begin{array}{c}\text { Organization } \\
(\mathrm{O})\end{array}$ & $\begin{array}{c}\text { Knowledge } \\
(\mathrm{K})\end{array}$ \\
\hline Griffith T.L. & $\begin{array}{l}\text { Technology features as triggers } \\
\text { for sensemaking }\end{array}$ & 1999 & $\begin{array}{l}\text { Academy of } \\
\text { Management } \\
\text { Review } \\
\end{array}$ & 229 & & 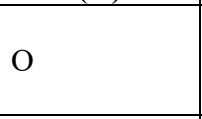 & \\
\hline $\begin{array}{l}\text { Suarez F.F., } \\
\text { Lanzolla G. }\end{array}$ & $\begin{array}{l}\text { The role of environmental } \\
\text { dynamics in building a first } \\
\text { mover advantage theory }\end{array}$ & 2007 & $\begin{array}{l}\text { Academy of } \\
\text { Management } \\
\text { Review }\end{array}$ & 137 & $P$ & & \\
\hline Leonardi P.M. & $\begin{array}{l}\text { Indeterminacy and the discourse } \\
\text { of inevitability in international } \\
\text { technology management }\end{array}$ & 2008 & $\begin{array}{l}\text { Academy of } \\
\text { Management } \\
\text { Review } \\
\end{array}$ & 27 & & $\mathrm{O}$ & \\
\hline $\begin{array}{l}\text { Grodal S., } \\
\text { Gotsopoulos A., } \\
\text { Suarez F.F. }\end{array}$ & $\begin{array}{l}\text { The coevolution of technologies } \\
\text { and categories during industry } \\
\text { emergence }\end{array}$ & 2015 & $\begin{array}{l}\text { Academy of } \\
\text { Management } \\
\text { Review }\end{array}$ & 9 & $P$ & & \\
\hline Dhebar A. & $\begin{array}{l}\text { Bringing new high-technology } \\
\text { products to market: Six perils } \\
\text { awaiting marketers }\end{array}$ & 2016 & $\begin{array}{l}\text { Business } \\
\text { Horizons }\end{array}$ & 1 & $P$ & & \\
\hline Adler P.S. & Managing Flexible Automation & 1988 & $\begin{array}{l}\text { California } \\
\text { Management } \\
\text { Review }\end{array}$ & 159 & & $\mathrm{O}$ & \\
\hline $\begin{array}{l}\text { Hall J., } \\
\text { Bachor V., } \\
\text { Matos S. }\end{array}$ & $\begin{array}{l}\text { Developing and diffusing new } \\
\text { technologies: Strategies for } \\
\text { legitimization }\end{array}$ & 2014 & $\begin{array}{l}\text { California } \\
\text { Management } \\
\text { Review }\end{array}$ & 7 & & $\mathrm{O}$ & \\
\hline $\begin{array}{l}\text { Gama F., } \\
\text { Sjödin D.R., } \\
\text { Frishammar J. }\end{array}$ & $\begin{array}{l}\text { Managing interorganizational } \\
\text { technology development: Project } \\
\text { management practices for } \\
\text { market- and science-based } \\
\text { partnerships }\end{array}$ & 2017 & $\begin{array}{l}\text { Creativity and } \\
\text { Innovation } \\
\text { Management }\end{array}$ & 0 & & & $\mathrm{~K}$ \\
\hline Drejer A. & $\begin{array}{l}\text { Integrating product and } \\
\text { technology development }\end{array}$ & 2000 & $\begin{array}{l}\text { European } \\
\text { Journal of } \\
\text { Innovation } \\
\text { Management }\end{array}$ & 10 & & $\mathrm{O}$ & \\
\hline $\begin{array}{l}\text { Magnusson T., } \\
\text { Johansson G. }\end{array}$ & $\begin{array}{l}\text { Managing internal technology } \\
\text { transfer in complex product } \\
\text { development }\end{array}$ & 2008 & $\begin{array}{l}\text { European } \\
\text { Journal of } \\
\text { Innovation } \\
\text { Management }\end{array}$ & 10 & & & $\mathrm{~K}$ \\
\hline $\begin{array}{l}\text { Patel C., } \\
\text { Haon C. }\end{array}$ & $\begin{array}{l}\text { Internally versus externally } \\
\text { developed technology and market } \\
\text { acceptance of innovations: The } \\
\text { complementary role of branding }\end{array}$ & 2014 & $\begin{array}{l}\text { European } \\
\text { Management } \\
\text { Review }\end{array}$ & 1 & & & $\mathrm{~K}$ \\
\hline $\begin{array}{l}\text { Buttner F.H., } \\
\text { Lanford H.W. }\end{array}$ & $\begin{array}{l}\text { Technology development: } \\
\text { Determining what to forecast }\end{array}$ & 1980 & $\begin{array}{l}\text { Industrial } \\
\text { Marketing } \\
\text { Management } \\
\end{array}$ & 1 & & & $\mathrm{~K}$ \\
\hline $\begin{array}{l}\text { Hashim N.H., } \\
\text { Murphy J., } \\
\text { Doina O., } \\
\text { O'Connor P. }\end{array}$ & $\begin{array}{l}\text { Bandwagon and leapfrog effects } \\
\text { in Internet implementation }\end{array}$ & 2014 & $\begin{array}{l}\text { International } \\
\text { Journal of } \\
\text { Hospitality } \\
\text { Management }\end{array}$ & 5 & & & $\mathrm{~K}$ \\
\hline $\begin{array}{l}\text { Verbeek A., } \\
\text { Debackere K., } \\
\text { Luwel M., } \\
\text { Zimmermann E. }\end{array}$ & $\begin{array}{l}\text { Measuring progress and evolution } \\
\text { in science and technology - I: The } \\
\text { multiple uses of bibliometric } \\
\text { indicators }\end{array}$ & 2002 & $\begin{array}{l}\text { International } \\
\text { Journal of } \\
\text { Management } \\
\text { Reviews }\end{array}$ & 76 & & & $\mathrm{~K}$ \\
\hline $\begin{array}{l}\text { Debackere K., } \\
\text { Verbeek A., } \\
\text { Luwel M., } \\
\text { Zimmermann E. }\end{array}$ & $\begin{array}{l}\text { Measuring progress and evolution } \\
\text { in science and technology - II: } \\
\text { The multiple uses of } \\
\text { technometric indicators }\end{array}$ & 2002 & $\begin{array}{l}\text { International } \\
\text { Journal of } \\
\text { Management } \\
\text { Reviews }\end{array}$ & 31 & & & $\mathrm{~K}$ \\
\hline
\end{tabular}




\begin{tabular}{|c|c|c|c|c|c|c|c|}
\hline $\begin{array}{l}\text { Phaal R., } \\
\text { Farrukh C.J.P., } \\
\text { Probert D.R. }\end{array}$ & $\begin{array}{l}\text { Technology management process } \\
\text { assessment: A case study }\end{array}$ & 2001 & \begin{tabular}{|l} 
International \\
Journal of \\
Operations \\
and \\
Production \\
Management
\end{tabular} & 42 & & & K \\
\hline $\begin{array}{l}\text { Karlsson C., } \\
\text { Taylor M., } \\
\text { Taylor A. }\end{array}$ & $\begin{array}{l}\text { Integrating new technology in } \\
\text { established organizations: A } \\
\text { mapping of integration } \\
\text { mechanisms }\end{array}$ & 2010 & \begin{tabular}{|l|} 
International \\
Journal of \\
Operations \\
and \\
Production \\
Management \\
\end{tabular} & 11 & $\mathrm{P}$ & & \\
\hline Kim B. & $\begin{array}{l}\text { Optimal development of } \\
\text { production technology when } \\
\text { autonomous and induced learning } \\
\text { are present }\end{array}$ & 1998 & $\begin{array}{l}\text { International } \\
\text { Journal of } \\
\text { Production } \\
\text { Economics }\end{array}$ & 3 & & & $\mathrm{~K}$ \\
\hline $\begin{array}{l}\text { Chung C.-J., } \\
\text { Wee H.-M. }\end{array}$ & $\begin{array}{l}\text { Green-component life-cycle } \\
\text { value on design and reverse } \\
\text { manufacturing in semi-closed } \\
\text { supply chain }\end{array}$ & 2008 & $\begin{array}{l}\text { International } \\
\text { Journal of } \\
\text { Production } \\
\text { Economics }\end{array}$ & 82 & $\mathrm{P}$ & & \\
\hline $\begin{array}{l}\text { Jha A., } \\
\text { Fernandes K., } \\
\text { Xiong Y., } \\
\text { Nie J., } \\
\text { Agarwal N., } \\
\text { Tiwari M.K. }\end{array}$ & $\begin{array}{l}\text { Effects of demand forecast and } \\
\text { resource sharing on collaborative } \\
\text { new product development in } \\
\text { supply chain }\end{array}$ & 2017 & $\begin{array}{l}\text { International } \\
\text { Journal of } \\
\text { Production } \\
\text { Economics }\end{array}$ & 0 & & & $\mathrm{~K}$ \\
\hline $\begin{array}{l}\text { Pillai A.S., } \\
\text { Joshi A., } \\
\text { Rao K.S. }\end{array}$ & $\begin{array}{l}\text { Performance measurement of } \mathrm{R} \\
\text { and } \mathrm{D} \text { projects in a multi-project, } \\
\text { concurrent engineering } \\
\text { environment }\end{array}$ & 2002 & $\begin{array}{l}\text { International } \\
\text { Journal of } \\
\text { Project } \\
\text { Management }\end{array}$ & 86 & & & $\mathrm{~K}$ \\
\hline $\begin{array}{l}\text { Garrety K., } \\
\text { Robertson P.L., } \\
\text { Badham R. }\end{array}$ & $\begin{array}{l}\text { Integrating communities of } \\
\text { practice in technology } \\
\text { development projects }\end{array}$ & 2004 & $\begin{array}{l}\text { International } \\
\text { Journal of } \\
\text { Project } \\
\text { Management }\end{array}$ & 52 & & & $\mathrm{~K}$ \\
\hline $\begin{array}{l}\text { Linton J.D., } \\
\text { Walsh S.T. }\end{array}$ & $\begin{array}{l}\text { Acceleration and extension of } \\
\text { opportunity recognition for } \\
\text { nanotechnologies and other } \\
\text { emerging technologies }\end{array}$ & 2008 & \begin{tabular}{|l|} 
International \\
Small \\
Business \\
Journal \\
\end{tabular} & 46 & $\mathrm{P}$ & & \\
\hline $\begin{array}{l}\text { Cooper S.Y., } \\
\text { Park J.S. }\end{array}$ & $\begin{array}{l}\text { The impact of 'incubator' } \\
\text { organizations on opportunity } \\
\text { recognition and technology } \\
\text { innovation in new, } \\
\text { entrepreneurial high-technology } \\
\text { ventures } \\
\end{array}$ & 2008 & $\begin{array}{l}\text { International } \\
\text { Small } \\
\text { Business } \\
\text { Journal }\end{array}$ & 40 & & $\mathrm{O}$ & \\
\hline $\begin{array}{l}\text { Galbraith C.S., } \\
\text { De Noble A.F. }\end{array}$ & $\begin{array}{l}\text { Competitive strategy and flexible } \\
\text { manufacturing: New dimensions } \\
\text { in high-technology venture-based } \\
\text { economic development }\end{array}$ & 1992 & $\begin{array}{l}\text { Journal of } \\
\text { Business } \\
\text { Venturing }\end{array}$ & 9 & & $\mathrm{O}$ & \\
\hline $\begin{array}{l}\text { Partidário P.J., } \\
\text { Vergragt P.J. }\end{array}$ & $\begin{array}{l}\text { Shaping sustainable technology } \\
\text { development in the coatings } \\
\text { chain Defining boundaries, } \\
\text { environmental problems and } \\
\text { main players }\end{array}$ & 2000 & $\begin{array}{l}\text { Journal of } \\
\text { Cleaner } \\
\text { Production }\end{array}$ & 8 & $\mathrm{P}$ & & \\
\hline Suzuki M. & $\begin{array}{l}\text { Identifying roles of international } \\
\text { institutions in clean energy } \\
\text { technology innovation and } \\
\text { diffusion in the developing } \\
\text { countries: Matching barriers with } \\
\text { roles of the institutions }\end{array}$ & 2015 & $\begin{array}{l}\text { Journal of } \\
\text { Cleaner } \\
\text { Production }\end{array}$ & 20 & & & $\mathrm{~K}$ \\
\hline $\begin{array}{l}\text { Planko J., } \\
\text { Cramer J.M., } \\
\text { Chappin M.M.H., } \\
\text { Hekkert M.P. }\end{array}$ & $\begin{array}{l}\text { Strategic collective system } \\
\text { building to commercialize } \\
\text { sustainability innovations }\end{array}$ & 2016 & $\begin{array}{l}\text { Journal of } \\
\text { Cleaner } \\
\text { Production }\end{array}$ & 3 & & & K \\
\hline
\end{tabular}




\begin{tabular}{|c|c|c|c|c|c|c|c|}
\hline $\begin{array}{l}\text { Gladysz B., } \\
\text { Kluczek A. }\end{array}$ & $\begin{array}{l}\text { A framework for strategic } \\
\text { assessment of far-reaching } \\
\text { technologies: A case study of } \\
\text { Combined Heat and Power } \\
\text { technology }\end{array}$ & 2018 & $\begin{array}{l}\text { Journal of } \\
\text { Cleaner } \\
\text { Production }\end{array}$ & 0 & $\mathrm{P}$ & & \\
\hline Sanderson S.W. & $\begin{array}{l}\text { Cost models for evaluating } \\
\text { virtual design strategies in } \\
\text { multicycle product families }\end{array}$ & 1991 & \begin{tabular}{|l} 
Journal of \\
Engineering \\
and \\
Technology \\
Management
\end{tabular} & 34 & $P$ & & \\
\hline $\begin{array}{l}\text { Choi T.Y., } \\
\text { Liker J.K. }\end{array}$ & $\begin{array}{l}\text { Institutional conformity and } \\
\text { technology implementation: A } \\
\text { process model of ergonomics } \\
\text { dissemination }\end{array}$ & 1992 & $\begin{array}{l}\text { Journal of } \\
\text { Engineering } \\
\text { and } \\
\text { Technology } \\
\text { Management }\end{array}$ & 7 & & $\mathrm{O}$ & \\
\hline $\begin{array}{l}\text { Lee J., } \\
\text { Bae Z.-T., } \\
\text { Lee J. }\end{array}$ & $\begin{array}{l}\text { Strategic management of a large- } \\
\text { scale technology development: } \\
\text { The case of the Korean } \\
\text { telecommunications industry }\end{array}$ & 1994 & $\begin{array}{l}\text { Journal of } \\
\text { Engineering } \\
\text { and } \\
\text { Technology } \\
\text { Management }\end{array}$ & 4 & $P$ & & \\
\hline Chung C.A. & $\begin{array}{l}\text { Human issues influencing the } \\
\text { successful implementation of } \\
\text { advanced manufacturing } \\
\text { technology }\end{array}$ & 1996 & $\begin{array}{l}\text { Journal of } \\
\text { Engineering } \\
\text { and } \\
\text { Technology } \\
\text { Management }\end{array}$ & 51 & & $\mathrm{O}$ & \\
\hline Griffith T.L. & $\begin{array}{l}\text { Negotiating successful } \\
\text { technology implementation: A } \\
\text { motivation perspective }\end{array}$ & 1996 & $\begin{array}{l}\text { Journal of } \\
\text { Engineering } \\
\text { and } \\
\text { Technology } \\
\text { Management }\end{array}$ & 19 & & & $\mathrm{~K}$ \\
\hline Chiesa V. & $\begin{array}{l}\text { Technology development control } \\
\text { styles in multinational } \\
\text { corporations: A case study }\end{array}$ & 1999 & $\begin{array}{l}\text { Journal of } \\
\text { Engineering } \\
\text { and } \\
\text { Technology } \\
\text { Management }\end{array}$ & 20 & & $\mathrm{O}$ & \\
\hline $\begin{array}{l}\text { Subramanian A.M., } \\
\text { Soh P.-H. }\end{array}$ & $\begin{array}{l}\text { An empirical examination of the } \\
\text { science-technology relationship } \\
\text { in the biotechnology industry }\end{array}$ & 2010 & $\begin{array}{l}\text { Journal of } \\
\text { Engineering } \\
\text { and } \\
\text { Technology } \\
\text { Management }\end{array}$ & 18 & & & K \\
\hline $\begin{array}{l}\text { Xu K., } \\
\text { Huang K.-F., } \\
\text { Gao S. }\end{array}$ & $\begin{array}{l}\text { Technology sourcing, } \\
\text { appropriability regimes, and new } \\
\text { product development }\end{array}$ & 2012 & $\begin{array}{l}\text { Journal of } \\
\text { Engineering } \\
\text { and } \\
\text { Technology } \\
\text { Management }\end{array}$ & 8 & $\mathrm{P}$ & & \\
\hline $\begin{array}{l}\text { Högman U., } \\
\text { Johannesson H. }\end{array}$ & $\begin{array}{l}\text { Applying stage-gate processes to } \\
\text { technology development - } \\
\text { Experience from six hardware- } \\
\text { oriented companies }\end{array}$ & 2013 & $\begin{array}{l}\text { Journal of } \\
\text { Engineering } \\
\text { and } \\
\text { Technology } \\
\text { Management }\end{array}$ & 11 & $P$ & & \\
\hline
\end{tabular}




\begin{tabular}{|c|c|c|c|c|c|c|c|}
\hline $\begin{array}{l}\text { Hung S.-C., } \\
\text { Lai J.-Y. }\end{array}$ & $\begin{array}{l}\text { When innovations meet chaos: } \\
\text { Analyzing the technology } \\
\text { development of printers in 1976- } \\
2012\end{array}$ & 2016 & $\begin{array}{l}\text { Journal of } \\
\text { Engineering } \\
\text { and } \\
\text { Technology } \\
\text { Management }\end{array}$ & 0 & $\mathrm{P}$ & & \\
\hline $\begin{array}{l}\text { Zedtwitz M., } \\
\text { Gassmann O., } \\
\text { Boutellier R. }\end{array}$ & $\begin{array}{l}\text { Organizing global R\&D: } \\
\text { Challenges and dilemmas }\end{array}$ & 2004 & $\begin{array}{l}\text { Journal of } \\
\text { International } \\
\text { Management }\end{array}$ & 65 & & $\mathrm{O}$ & \\
\hline $\begin{array}{l}\text { Hsu S.T.-H., } \\
\text { Iriyama A., } \\
\text { Prescott J.E. }\end{array}$ & $\begin{array}{l}\text { Lost in Translation or Lost in } \\
\text { Your Neighbor's Yard: The } \\
\text { Moderating Role of Leverage and } \\
\text { Protection Mechanisms for the } \\
\text { MNC Subsidiary Technology } \\
\text { Sourcing-Performance } \\
\text { Relationship } \\
\end{array}$ & 2016 & $\begin{array}{l}\text { Journal of } \\
\text { International } \\
\text { Management }\end{array}$ & 2 & & & $\mathrm{~K}$ \\
\hline $\begin{array}{l}\text { Foos T., } \\
\text { Schum G., } \\
\text { Rothenberg S. }\end{array}$ & $\begin{array}{l}\text { Tacit knowledge transfer and the } \\
\text { knowledge disconnect }\end{array}$ & 2006 & \begin{tabular}{|l} 
Journal of \\
Knowledge \\
Management
\end{tabular} & 61 & & & $\mathrm{~K}$ \\
\hline $\begin{array}{l}\text { Hu P.J., } \\
\text { Chau P.Y.K., } \\
\text { Liu Sheng O.R., } \\
\text { Tam K.Y. }\end{array}$ & $\begin{array}{l}\text { Examining the Technology } \\
\text { Acceptance Model Using } \\
\text { Physician Acceptance of } \\
\text { Telemedicine Technology }\end{array}$ & 1999 & \begin{tabular}{|l|} 
Journal of \\
Management \\
Information \\
Systems \\
\end{tabular} & 820 & & & $\mathrm{~K}$ \\
\hline $\begin{array}{l}\text { Maruping L., } \\
\text { Magni M. }\end{array}$ & $\begin{array}{l}\text { What's the weather like? the } \\
\text { effect of team learning climate, } \\
\text { empowerment climate, and } \\
\text { gender on individuals' technology } \\
\text { exploration and use }\end{array}$ & 2012 & $\begin{array}{l}\text { Journal of } \\
\text { Management } \\
\text { Information } \\
\text { Systems }\end{array}$ & 35 & & $\mathrm{O}$ & \\
\hline $\begin{array}{l}\text { Leten B., } \\
\text { Belderbos R., } \\
\text { Van Looy B. }\end{array}$ & $\begin{array}{l}\text { Entry and Technological } \\
\text { Performance in New Technology } \\
\text { Domains: Technological } \\
\text { Opportunities, Technology } \\
\text { Competition and Technological } \\
\text { Relatedness } \\
\end{array}$ & 2016 & $\begin{array}{l}\text { Journal of } \\
\text { Management } \\
\text { Studies }\end{array}$ & 0 & $\mathrm{P}$ & & \\
\hline $\begin{array}{l}\text { Stock G.N., } \\
\text { Tatikonda M.V. }\end{array}$ & $\begin{array}{l}\text { The joint influence of technology } \\
\text { uncertainty and } \\
\text { interorganizational interaction on } \\
\text { external technology integration } \\
\text { success }\end{array}$ & 2008 & $\begin{array}{l}\text { Journal of } \\
\text { Operations } \\
\text { Management }\end{array}$ & 64 & P & & \\
\hline Papas C. & $\begin{array}{l}\text { STRATEGIC MANAGEMENT } \\
\text { OF TECHNOLOGY. }\end{array}$ & 1984 & \begin{tabular}{|l|} 
Journal of \\
Product \\
Innovation \\
Management \\
\end{tabular} & 20 & & & $\mathrm{~K}$ \\
\hline $\begin{array}{l}\text { Sen F., } \\
\text { Rubenstein A.H. }\end{array}$ & $\begin{array}{l}\text { External technology and in-house } \\
\text { R\&D's facilitative role }\end{array}$ & 1989 & \begin{tabular}{|l} 
Journal of \\
Product \\
Innovation \\
Management
\end{tabular} & 34 & & & $\mathrm{~K}$ \\
\hline Tatikonda M.V. & $\begin{array}{l}\text { An empirical study of platform } \\
\text { and derivative product } \\
\text { development projects }\end{array}$ & 1999 & \begin{tabular}{|l|} 
Journal of \\
Product \\
Innovation \\
Management \\
\end{tabular} & 86 & & & $\mathrm{~K}$ \\
\hline $\begin{array}{l}\text { Swan K.S., } \\
\text { Allred B.B. }\end{array}$ & $\begin{array}{l}\text { A product and process model of } \\
\text { the technology-sourcing decision }\end{array}$ & 2003 & \begin{tabular}{|l|} 
Journal of \\
Product \\
Innovation \\
Management \\
\end{tabular} & 59 & & & $\mathrm{~K}$ \\
\hline $\begin{array}{l}\text { Staudenmayer N.A., } \\
\text { Tripsas M., } \\
\text { Tucci C.L. }\end{array}$ & $\begin{array}{l}\text { Interfirm modularity and its } \\
\text { implications for product } \\
\text { development }\end{array}$ & 2005 & \begin{tabular}{|l|} 
Journal of \\
Product \\
Innovation \\
Management
\end{tabular} & 91 & & $\mathrm{O}$ & \\
\hline
\end{tabular}




\begin{tabular}{|c|c|c|c|c|c|c|c|}
\hline $\begin{array}{l}\text { Caerteling J.S., } \\
\text { Halman J.I.M., } \\
\text { Dorée A.G. }\end{array}$ & $\begin{array}{l}\text { Technology commercialization in } \\
\text { road infrastructure: How } \\
\text { government affects the variation } \\
\text { and appropriability of technology }\end{array}$ & 2008 & $\begin{array}{l}\text { Journal of } \\
\text { Product } \\
\text { Innovation } \\
\text { Management }\end{array}$ & 30 & & & K \\
\hline $\begin{array}{l}\text { Song L.Z., } \\
\text { Song M., } \\
\text { Parry M.E. }\end{array}$ & $\begin{array}{l}\text { Perspective: Economic } \\
\text { conditions, entrepreneurship, } \\
\text { first-product development, and } \\
\text { new venture success }\end{array}$ & 2010 & \begin{tabular}{|l} 
Journal of \\
Product \\
Innovation \\
Management
\end{tabular} & 9 & $\mathrm{P}$ & & \\
\hline $\begin{array}{l}\text { Sköld M., } \\
\text { Karlsson C. }\end{array}$ & $\begin{array}{l}\text { Technology sharing in } \\
\text { manufacturing business groups }\end{array}$ & 2012 & $\begin{array}{l}\text { Journal of } \\
\text { Product } \\
\text { Innovation } \\
\text { Management }\end{array}$ & 3 & $\mathrm{P}$ & & \\
\hline $\begin{array}{l}\text { Song M., } \\
\text { Hooshangi S., } \\
\text { Zhao Y.L., } \\
\text { Halman J.I.M. }\end{array}$ & $\begin{array}{l}\text { How does technological regime } \\
\text { affect performance of technology } \\
\text { development projects? }\end{array}$ & 2014 & $\begin{array}{l}\text { Journal of } \\
\text { Product } \\
\text { Innovation } \\
\text { Management }\end{array}$ & 3 & & & K \\
\hline $\begin{array}{l}\text { Vanhaverbeke W., } \\
\text { Belderbos R., } \\
\text { Duysters G., } \\
\text { Beerkens B. }\end{array}$ & $\begin{array}{l}\text { Technological performance and } \\
\text { alliances over the industry life } \\
\text { cycle: Evidence from the ASIC } \\
\text { industry }\end{array}$ & 2015 & $\begin{array}{l}\text { Journal of } \\
\text { Product } \\
\text { Innovation } \\
\text { Management }\end{array}$ & 6 & & & K \\
\hline $\begin{array}{l}\text { Zhang F., } \\
\text { Wang Y., } \\
\text { Li D., } \\
\text { Cui V. }\end{array}$ & $\begin{array}{l}\text { Configurations of Innovations } \\
\text { across Domains: An } \\
\text { Organizational Ambidexterity } \\
\text { View }\end{array}$ & 2017 & $\begin{array}{l}\text { Journal of } \\
\text { Product } \\
\text { Innovation } \\
\text { Management }\end{array}$ & 0 & $\mathrm{P}$ & & \\
\hline $\begin{array}{l}\text { Baughn C.C., } \\
\text { Osborne R.N. }\end{array}$ & $\begin{array}{l}\text { Strategies for successful } \\
\text { technological development }\end{array}$ & 1989 & $\begin{array}{l}\text { Journal of } \\
\text { Technology } \\
\text { Transfer } \\
\end{array}$ & 4 & & $\mathrm{O}$ & \\
\hline $\begin{array}{l}\text { Frank C., } \\
\text { Sink C., } \\
\text { Mynatt L., } \\
\text { Rogers R., } \\
\text { Rappazzo A. }\end{array}$ & $\begin{array}{l}\text { Surviving the valley of death: A } \\
\text { comparative analysis }\end{array}$ & 1996 & $\begin{array}{l}\text { Journal of } \\
\text { Technology } \\
\text { Transfer }\end{array}$ & 16 & $\mathrm{P}$ & & \\
\hline $\begin{array}{l}\text { Tippett D.D., } \\
\text { Grubb R.G. }\end{array}$ & $\begin{array}{l}\text { Environmental remediation } \\
\text { technology implementation } \\
\text { decision patterns }\end{array}$ & 1996 & $\begin{array}{l}\text { Journal of } \\
\text { Technology } \\
\text { Transfer } \\
\end{array}$ & 0 & $\mathrm{P}$ & & \\
\hline Hayter C.S. & $\begin{array}{l}\text { In search of the profit- } \\
\text { maximizing actor: Motivations } \\
\text { and definitions of success from } \\
\text { nascent academic entrepreneurs }\end{array}$ & 2011 & $\begin{array}{l}\text { Journal of } \\
\text { Technology } \\
\text { Transfer }\end{array}$ & 36 & & & K \\
\hline Andersen M.M. & $\begin{array}{l}\text { Silent innovation: Corporate } \\
\text { strategizing in early } \\
\text { nanotechnology evolution }\end{array}$ & 2011 & \begin{tabular}{|l|} 
Journal of \\
Technology \\
Transfer \\
\end{tabular} & 7 & & $\mathrm{O}$ & \\
\hline $\begin{array}{l}\text { Bradley S.R., } \\
\text { Hayter C.S., } \\
\text { Link A.N. }\end{array}$ & $\begin{array}{l}\text { Proof of Concept Centers in the } \\
\text { United States: An exploratory } \\
\text { look }\end{array}$ & 2013 & $\begin{array}{l}\text { Journal of } \\
\text { Technology } \\
\text { Transfer }\end{array}$ & 15 & & $\mathrm{O}$ & \\
\hline $\begin{array}{l}\text { Kirchberger M.A., } \\
\text { Pohl L. }\end{array}$ & $\begin{array}{l}\text { Technology commercialization: a } \\
\text { literature review of success } \\
\text { factors and antecedents across } \\
\text { different contexts }\end{array}$ & 2016 & $\begin{array}{l}\text { Journal of } \\
\text { Technology } \\
\text { Transfer }\end{array}$ & 2 & & & K \\
\hline Nakamura G.-I. & $\begin{array}{l}\text { Strategic management in major } \\
\text { Japanese hightech companies }\end{array}$ & 1986 & $\begin{array}{l}\text { Long Range } \\
\text { Planning }\end{array}$ & 8 & & $\mathrm{O}$ & \\
\hline Zairi M. & $\begin{array}{l}\text { Managing User-supplier } \\
\text { Interactions: Management of } \\
\text { R\&D Activity }\end{array}$ & 1992 & $\begin{array}{l}\text { Management } \\
\text { Decision }\end{array}$ & 10 & & $\mathrm{O}$ & \\
\hline $\begin{array}{l}\text { Gomez-Arias T.J., } \\
\text { Montermoso J.P. }\end{array}$ & $\begin{array}{l}\text { Initial reference customer } \\
\text { selection for high technology } \\
\text { products }\end{array}$ & 2007 & $\begin{array}{l}\text { Management } \\
\text { Decision }\end{array}$ & 8 & $\mathrm{P}$ & & \\
\hline $\begin{array}{l}\text { Movahedipour M., } \\
\text { Zeng J., } \\
\text { Yang M., } \\
\text { Wu X. }\end{array}$ & $\begin{array}{l}\text { An ISM approach for the barrier } \\
\text { analysis in implementing } \\
\text { sustainable supply chain } \\
\text { management: An empirical study }\end{array}$ & 2017 & $\begin{array}{l}\text { Management } \\
\text { Decision }\end{array}$ & 0 & $\mathrm{P}$ & & \\
\hline
\end{tabular}




\begin{tabular}{|c|c|c|c|c|c|c|c|}
\hline $\begin{array}{l}\text { Sood A., } \\
\text { James G.M., } \\
\text { Tellis G.J., } \\
\text { Zhu J. }\end{array}$ & $\begin{array}{l}\text { Predicting the path of } \\
\text { technological innovation: SAW } \\
\text { vs. Moore, Bass, Gompertz, and } \\
\text { Kryder }\end{array}$ & 2012 & $\begin{array}{l}\text { Marketing } \\
\text { Science }\end{array}$ & 11 & $P$ & & \\
\hline $\begin{array}{l}\text { Nambisan S., } \\
\text { Agarwal R., } \\
\text { Tanniru M. }\end{array}$ & $\begin{array}{l}\text { Organizational mechanisms for } \\
\text { enhancing user innovation in } \\
\text { information technology }\end{array}$ & 1999 & $\begin{array}{l}\text { MIS } \\
\text { Quarterly: } \\
\text { Management } \\
\text { Information } \\
\text { Systems }\end{array}$ & 226 & $\mathrm{P}$ & & \\
\hline $\begin{array}{l}\text { Rivard S., } \\
\text { Lapointe L. }\end{array}$ & $\begin{array}{l}\text { Information technology } \\
\text { implementers' responses to user } \\
\text { resistance: Nature and effects }\end{array}$ & 2012 & $\begin{array}{l}\text { MIS } \\
\text { Quarterly: } \\
\text { Management } \\
\text { Information } \\
\text { Systems } \\
\end{array}$ & 66 & & & K \\
\hline Leonardi P.M. & $\begin{array}{l}\text { When does technology use enable } \\
\text { network change in organizations? } \\
\text { A comparative study of feature } \\
\text { use and shared affordances }\end{array}$ & 2013 & $\begin{array}{l}\text { MIS } \\
\text { Quarterly: } \\
\text { Management } \\
\text { Information } \\
\text { Systems } \\
\end{array}$ & 61 & & & K \\
\hline $\begin{array}{l}\text { Leonardi P.M., } \\
\text { Bailey D.E., } \\
\text { Diniz E.H., } \\
\text { Sholler D., } \\
\text { Nardi B. }\end{array}$ & $\begin{array}{l}\text { Multiplex appropriation in } \\
\text { complex systems } \\
\text { implementation: The case of } \\
\text { Brazil's correspondent banking } \\
\text { system }\end{array}$ & 2016 & $\begin{array}{l}\text { MIS } \\
\text { Quarterly: } \\
\text { Management } \\
\text { Information } \\
\text { Systems }\end{array}$ & 1 & & & K \\
\hline $\begin{array}{l}\text { McAdam R., } \\
\text { Leonard D., } \\
\text { Henderson J., } \\
\text { Hazlett S.-A. }\end{array}$ & $\begin{array}{l}\text { A grounded theory research } \\
\text { approach to building and testing } \\
\text { TQM theory in operations } \\
\text { management }\end{array}$ & 2008 & Omega & 23 & $P$ & & \\
\hline Taylor A. & $\begin{array}{l}\text { The next generation: Technology } \\
\text { adoption and integration through } \\
\text { internal competition in new } \\
\text { product development }\end{array}$ & 2010 & $\begin{array}{l}\text { Organization } \\
\text { Science }\end{array}$ & 22 & $\mathrm{P}$ & & \\
\hline $\begin{array}{l}\text { Li D., } \\
\text { Eden L., } \\
\text { Hitt M.A., } \\
\text { Ireland R.D., } \\
\text { Garrett R.P. }\end{array}$ & $\begin{array}{l}\text { Governance in multilateral R \& D } \\
\text { alliances }\end{array}$ & 2012 & $\begin{array}{l}\text { Organization } \\
\text { Science }\end{array}$ & 29 & & $\mathrm{O}$ & \\
\hline Sahay S. & $\begin{array}{l}\text { Implementation of information } \\
\text { technology: A time-space } \\
\text { perspective }\end{array}$ & 1997 & $\begin{array}{l}\text { Organization } \\
\text { Studies }\end{array}$ & 47 & & & K \\
\hline $\begin{array}{l}\text { Bhaneja B., } \\
\text { Lyrette J., } \\
\text { Davies T.W., } \\
\text { Dohoo R.M. }\end{array}$ & $\begin{array}{l}\text { Technology transfer from } \\
\text { government laboratories to } \\
\text { industry: Canadian experience in } \\
\text { the communications sector }\end{array}$ & 1982 & $\begin{array}{l}\text { R\&D } \\
\text { Management }\end{array}$ & 3 & $P$ & & \\
\hline $\begin{array}{l}\text { Lee J., } \\
\text { Bae Z.-T., } \\
\text { Choi D.-K. }\end{array}$ & $\begin{array}{l}\text { Technology development } \\
\text { processes: A model for a } \\
\text { developing country with a global } \\
\text { perspective }\end{array}$ & 1988 & $\begin{array}{l}\text { R\&D } \\
\text { Management }\end{array}$ & 107 & & & K \\
\hline $\begin{array}{l}\text { Allen T.J., } \\
\text { George V. }\end{array}$ & $\begin{array}{l}\text { Changes in the field of } \mathrm{R} \& \mathrm{D} \\
\text { management over the past } 20 \\
\text { years }\end{array}$ & 1989 & $\begin{array}{l}\text { R\&D } \\
\text { Management }\end{array}$ & 8 & & & K \\
\hline $\begin{array}{l}\text { Contractor F.J., } \\
\text { Narayanan V.K. }\end{array}$ & $\begin{array}{l}\text { Technology development in the } \\
\text { multinational firm: a framework } \\
\text { for planning and strategy }\end{array}$ & 1990 & $\begin{array}{l}\text { R\&D } \\
\text { Management }\end{array}$ & 13 & $\mathrm{P}$ & & \\
\hline $\begin{array}{l}\text { Bidault F., } \\
\text { Fischer W.A. }\end{array}$ & $\begin{array}{l}\text { Technology transactions: } \\
\text { networks over markets }\end{array}$ & 1994 & $\begin{array}{l}\text { R\&D } \\
\text { Management }\end{array}$ & 65 & $P$ & & \\
\hline $\begin{array}{l}\text { Kim Y., } \\
\text { Lee K. }\end{array}$ & $\begin{array}{l}\text { Technological collaboration in } \\
\text { the Korean electronic parts } \\
\text { industry: Patterns and key } \\
\text { success factors }\end{array}$ & 2003 & $\begin{array}{l}\text { R\&D } \\
\text { Management }\end{array}$ & 23 & & $\mathrm{O}$ & \\
\hline Harryson S.J. & $\begin{array}{l}\text { Entrepreneurship through } \\
\text { relationships - Navigating from } \\
\text { creativity to commercialisation }\end{array}$ & 2008 & $\begin{array}{l}\text { R\&D } \\
\text { Management }\end{array}$ & 31 & & $\mathrm{O}$ & \\
\hline
\end{tabular}




\begin{tabular}{|c|c|c|c|c|c|c|c|}
\hline $\begin{array}{l}\text { Lee J.H., } \\
\text { Phaal R., } \\
\text { Lee C. }\end{array}$ & $\begin{array}{l}\text { An empirical analysis of the } \\
\text { determinants of technology } \\
\text { roadmap utilization }\end{array}$ & 2011 & $\begin{array}{l}\text { R\&D } \\
\text { Management }\end{array}$ & 7 & $\mathrm{P}$ & & \\
\hline $\begin{array}{l}\text { Dhewanto W., } \\
\text { Sohal A.S. }\end{array}$ & $\begin{array}{l}\text { The relationship between } \\
\text { organisational orientation and } \\
\text { research and } \\
\text { development/technology } \\
\text { commercialisation performance }\end{array}$ & 2015 & $\begin{array}{l}\text { R\&D } \\
\text { Management }\end{array}$ & 2 & & & $\mathrm{~K}$ \\
\hline $\begin{array}{l}\text { Lee K., } \\
\text { Yoon B. }\end{array}$ & $\begin{array}{l}\text { The idiosyncrasy of research and } \\
\text { development efficiency across } \\
\text { types of small- and medium-sized } \\
\text { enterprises: Evidence from Korea }\end{array}$ & 2015 & $\begin{array}{l}\text { R\&D } \\
\text { Management }\end{array}$ & 1 & & $\mathrm{O}$ & \\
\hline Zuscovitch E. & $\begin{array}{l}\text { The economic dynamics of } \\
\text { technologies development }\end{array}$ & 1986 & \begin{tabular}{|l|} 
Research \\
Policy
\end{tabular} & 15 & $\mathrm{P}$ & & \\
\hline Chaudhuri S. & $\begin{array}{l}\text { Technological innovation in a } \\
\text { research laboratory in India: A } \\
\text { case study }\end{array}$ & 1986 & $\begin{array}{l}\text { Research } \\
\text { Policy }\end{array}$ & 10 & $P$ & & \\
\hline Gates W. & $\begin{array}{l}\text { Federally supported commercial } \\
\text { technology development: Solar } \\
\text { thermal technologies 1970-1982 }\end{array}$ & 1988 & $\begin{array}{l}\text { Research } \\
\text { Policy }\end{array}$ & 6 & & & K \\
\hline Slaughter S. & $\begin{array}{l}\text { Innovation and learning during } \\
\text { implementation: a comparison of } \\
\text { user and manufacturer } \\
\text { innovations }\end{array}$ & 1993 & $\begin{array}{l}\text { Research } \\
\text { Policy }\end{array}$ & 80 & $\mathrm{P}$ & & \\
\hline $\begin{array}{l}\text { Cusumano M.A., } \\
\text { Elenkov D. }\end{array}$ & $\begin{array}{l}\text { Linking international technology } \\
\text { transfer with strategy and } \\
\text { management: a literature } \\
\text { commentary }\end{array}$ & 1994 & $\begin{array}{l}\text { Research } \\
\text { Policy }\end{array}$ & 64 & & & K \\
\hline Garud R. & $\begin{array}{l}\text { Cooperative and competitive } \\
\text { behaviors during the process of } \\
\text { creative destruction }\end{array}$ & 1994 & $\begin{array}{l}\text { Research } \\
\text { Policy }\end{array}$ & 23 & $\mathrm{P}$ & & \\
\hline $\begin{array}{l}\text { Christensen C.M., } \\
\text { Rosenbloom R.S. }\end{array}$ & $\begin{array}{l}\text { Explaining the attacker's } \\
\text { advantage: Technological } \\
\text { paradigms, organizational } \\
\text { dynamics, and the value network }\end{array}$ & 1995 & $\begin{array}{l}\text { Research } \\
\text { Policy }\end{array}$ & 473 & & $\mathrm{O}$ & \\
\hline Iansiti M. & $\begin{array}{l}\text { Technology integration: } \\
\text { Managing technological } \\
\text { evolution in a complex } \\
\text { environment }\end{array}$ & 1995 & $\begin{array}{l}\text { Research } \\
\text { Policy }\end{array}$ & 140 & & & K \\
\hline Iansiti M. & $\begin{array}{l}\text { From technological potential to } \\
\text { product performance: An } \\
\text { empirical analysis }\end{array}$ & 1997 & $\begin{array}{l}\text { Research } \\
\text { Policy }\end{array}$ & 39 & & & K \\
\hline $\begin{array}{l}\text { Clarysse B., } \\
\text { Muldur U. }\end{array}$ & $\begin{array}{l}\text { Regional cohesion in Europe? An } \\
\text { analysis of how EU public RTD } \\
\text { support influences the techno- } \\
\text { economic regional landscape }\end{array}$ & 2001 & $\begin{array}{l}\text { Research } \\
\text { Policy }\end{array}$ & 33 & $P$ & & \\
\hline Ekboir J.M. & $\begin{array}{l}\text { Research and technology policies } \\
\text { in innovation systems: Zero } \\
\text { tillage in Brazil }\end{array}$ & 2003 & $\begin{array}{l}\text { Research } \\
\text { Policy }\end{array}$ & 52 & & $\mathrm{O}$ & \\
\hline Schmoch U. & $\begin{array}{l}\text { Double-boom cycles and the } \\
\text { comeback of science-push and } \\
\text { market-pull }\end{array}$ & 2007 & $\begin{array}{l}\text { Research } \\
\text { Policy }\end{array}$ & 67 & $\mathrm{P}$ & & \\
\hline Johnson W.H.A. & $\begin{array}{l}\text { Managing university technology } \\
\text { development using organizational } \\
\text { control theory }\end{array}$ & 2011 & $\begin{array}{l}\text { Research } \\
\text { Policy }\end{array}$ & 10 & & & K \\
\hline $\begin{array}{l}\text { Lehoux P., } \\
\text { Daudelin G., } \\
\text { Williams-Jones B., } \\
\text { Denis J.-L., } \\
\text { Longo C. }\end{array}$ & $\begin{array}{l}\text { How do business model and } \\
\text { health technology design } \\
\text { influence each other? Insights } \\
\text { from a longitudinal case study of } \\
\text { three academic spin-offs }\end{array}$ & 2014 & $\begin{array}{l}\text { Research } \\
\text { Policy }\end{array}$ & 21 & $\mathrm{P}$ & & \\
\hline $\begin{array}{l}\text { Costantini V., } \\
\text { Crespi F., } \\
\text { Martini C., } \\
\text { Pennacchio L., }\end{array}$ & $\begin{array}{l}\text { Demand-pull and technology- } \\
\text { push public support for eco- } \\
\text { innovation: The case of the } \\
\text { biofuels sector }\end{array}$ & 2015 & $\begin{array}{l}\text { Research } \\
\text { Policy }\end{array}$ & 26 & & & K \\
\hline
\end{tabular}




\begin{tabular}{|c|c|c|c|c|c|c|c|}
\hline $\begin{array}{l}\text { Gilbert B.A., } \\
\text { Campbell J.T. }\end{array}$ & $\begin{array}{l}\text { The geographic origins of radical } \\
\text { technological paradigms: A } \\
\text { configurational study }\end{array}$ & 2015 & $\begin{array}{l}\text { Research } \\
\text { Policy }\end{array}$ & 6 & & $\mathrm{O}$ & \\
\hline $\begin{array}{l}\text { Hellsmark H., } \\
\text { Frishammar J., } \\
\text { Söderholm P., } \\
\text { Ylinenpää H. }\end{array}$ & $\begin{array}{l}\text { The role of pilot and } \\
\text { demonstration plants in } \\
\text { technology development and } \\
\text { innovation policy }\end{array}$ & 2016 & $\begin{array}{l}\text { Research } \\
\text { Policy }\end{array}$ & 6 & & & K \\
\hline $\begin{array}{l}\text { Aharonson B.S., } \\
\text { Schilling M.A. }\end{array}$ & $\begin{array}{l}\text { Mapping the technological } \\
\text { landscape: Measuring technology } \\
\text { distance, technological footprints, } \\
\text { and technology evolution }\end{array}$ & 2016 & $\begin{array}{l}\text { Research } \\
\text { Policy }\end{array}$ & 3 & & & K \\
\hline Popp D. & $\begin{array}{l}\text { From science to technology: The } \\
\text { value of knowledge from } \\
\text { different energy research } \\
\text { institutions }\end{array}$ & 2017 & $\begin{array}{l}\text { Research } \\
\text { Policy }\end{array}$ & 0 & & & K \\
\hline $\begin{array}{l}\text { Tyler B.B., } \\
\text { Steensma K. H. }\end{array}$ & $\begin{array}{l}\text { Evaluating technological } \\
\text { collaborative opportunities: A } \\
\text { cognitive modeling perspective }\end{array}$ & 1995 & $\begin{array}{l}\text { Strategic } \\
\text { Management } \\
\text { Journal }\end{array}$ & 136 & $\mathrm{P}$ & & \\
\hline $\begin{array}{l}\text { Robertson T.S., } \\
\text { Gatignon H. }\end{array}$ & $\begin{array}{l}\text { Technology development mode: } \\
\text { A transaction cost } \\
\text { conceptualization }\end{array}$ & 1998 & $\begin{array}{l}\text { Strategic } \\
\text { Management } \\
\text { Journal }\end{array}$ & 220 & & $\mathrm{O}$ & \\
\hline Adner R. & $\begin{array}{l}\text { When are technologies } \\
\text { disruptive? A demand-based view } \\
\text { of the emergence of competition }\end{array}$ & 2002 & $\begin{array}{l}\text { Strategic } \\
\text { Management } \\
\text { Journal }\end{array}$ & 263 & $\mathrm{P}$ & & \\
\hline $\begin{array}{l}\text { Adner R., } \\
\text { Kapoor R. }\end{array}$ & $\begin{array}{l}\text { Innovation ecosystems and the } \\
\text { pace of substitution: Re- } \\
\text { examining technology S-curves }\end{array}$ & 2016 & $\begin{array}{l}\text { Strategic } \\
\text { Management } \\
\text { Journal } \\
\end{array}$ & 11 & & $\mathrm{O}$ & \\
\hline Lee C.-O. & $\begin{array}{l}\text { The role of the government and } \\
\text { R\&D infrastructure for } \\
\text { technology development }\end{array}$ & 1988 & $\begin{array}{l}\text { Technological } \\
\text { Forecasting } \\
\text { and Social } \\
\text { Change } \\
\end{array}$ & 9 & & $\mathrm{O}$ & \\
\hline $\begin{array}{l}\text { Cho Y.Y., } \\
\text { Jeong G.H., } \\
\text { Kim S.H. }\end{array}$ & $\begin{array}{l}\text { A Delphi technology forecasting } \\
\text { approach using a semi-Markov } \\
\text { concept }\end{array}$ & 1991 & $\begin{array}{l}\text { Technological } \\
\text { Forecasting } \\
\text { and Social } \\
\text { Change }\end{array}$ & 24 & $\mathrm{P}$ & & \\
\hline Tarr S.C. & $\begin{array}{l}\text { Multiple perspectives analysis for } \\
\text { integrating technology into a } \\
\text { business. A knowledge systems } \\
\text { case study }\end{array}$ & 1991 & $\begin{array}{l}\text { Technological } \\
\text { Forecasting } \\
\text { and Social } \\
\text { Change }\end{array}$ & 3 & & & K \\
\hline Dror I. & $\begin{array}{l}\text { The process of technology } \\
\text { evolution. Multitechnology } \\
\text { innovations as the driving force }\end{array}$ & 1993 & $\begin{array}{l}\text { Technological } \\
\text { Forecasting } \\
\text { and Social } \\
\text { Change } \\
\end{array}$ & 1 & $\mathrm{P}$ & & \\
\hline $\begin{array}{l}\text { Kwaśnicki W., } \\
\text { Kwaśnicka H. }\end{array}$ & $\begin{array}{l}\text { Long-term diffusion factors of } \\
\text { technological development: An } \\
\text { evolutionary model and case } \\
\text { study }\end{array}$ & 1996 & $\begin{array}{l}\text { Technological } \\
\text { Forecasting } \\
\text { and Social } \\
\text { Change } \\
\end{array}$ & 19 & $\mathrm{P}$ & & \\
\hline Inzelt A. & $\begin{array}{l}\text { Institutional support for } \\
\text { technological improvement - The } \\
\text { case of Hungary }\end{array}$ & 1996 & $\begin{array}{l}\text { Technological } \\
\text { Forecasting } \\
\text { and Social } \\
\text { Change } \\
\end{array}$ & 5 & & & K \\
\hline Guerin T.F. & $\begin{array}{l}\text { Transferring environmental } \\
\text { technologies to China: Recent } \\
\text { developments and constraints }\end{array}$ & 2001 & $\begin{array}{l}\text { Technological } \\
\text { Forecasting } \\
\text { and Social } \\
\text { Change }\end{array}$ & 17 & & & K \\
\hline Mowery D.C. & $\begin{array}{l}\text { Technological innovation in a } \\
\text { multipolar system: Analysis and } \\
\text { implications for U.S. policy }\end{array}$ & 2001 & $\begin{array}{l}\text { Technological } \\
\text { Forecasting } \\
\text { and Social } \\
\text { Change }\end{array}$ & 8 & & $\mathrm{O}$ & \\
\hline
\end{tabular}




\begin{tabular}{|c|c|c|c|c|c|c|c|}
\hline $\begin{array}{l}\text { Watanabe C., } \\
\text { Zhu B., } \\
\text { Miyazawa T. }\end{array}$ & $\begin{array}{l}\text { Hierarchical impacts of the length } \\
\text { of technology waves: An analysis } \\
\text { of technolabor homeostasis }\end{array}$ & 2001 & \begin{tabular}{|l|} 
Technological \\
Forecasting \\
and Social \\
Change \\
\end{tabular} & 7 & & $\mathrm{O}$ & \\
\hline Phaal R. & $\begin{array}{l}\text { Technology roadmapping - A } \\
\text { planning framework for evolution } \\
\text { and revolution }\end{array}$ & 2004 & $\begin{array}{l}\text { Technological } \\
\text { Forecasting } \\
\text { and Social } \\
\text { Change } \\
\end{array}$ & 449 & $\mathrm{P}$ & & \\
\hline $\begin{array}{l}\text { Wang M.-Y., } \\
\text { Lan W.-T. }\end{array}$ & $\begin{array}{l}\text { Combined forecast process: } \\
\text { Combining scenario analysis with } \\
\text { the technological substitution } \\
\text { model }\end{array}$ & 2007 & $\begin{array}{l}\text { Technological } \\
\text { Forecasting } \\
\text { and Social } \\
\text { Change }\end{array}$ & 32 & $\mathrm{P}$ & & \\
\hline $\begin{array}{l}\text { Lin C.-H., } \\
\text { Liou D.-Y., } \\
\text { Wu K.-W. }\end{array}$ & $\begin{array}{l}\text { Opportunities and challenges } \\
\text { created by terrorism }\end{array}$ & 2007 & $\begin{array}{l}\text { Technological } \\
\text { Forecasting } \\
\text { and Social } \\
\text { Change }\end{array}$ & 14 & & & K \\
\hline $\begin{array}{l}\text { Un S., } \\
\text { Price N. }\end{array}$ & $\begin{array}{l}\text { Bridging the gap between } \\
\text { technological possibilities and } \\
\text { people:. Involving people in the } \\
\text { early phases of technology } \\
\text { development }\end{array}$ & 2007 & $\begin{array}{l}\text { Technological } \\
\text { Forecasting } \\
\text { and Social } \\
\text { Change }\end{array}$ & 11 & & $\mathrm{O}$ & \\
\hline $\begin{array}{l}\text { Roelofsen A., } \\
\text { Broerse J.E.W., } \\
\text { de Cock Buning T., } \\
\text { Bunders J.F.G. }\end{array}$ & $\begin{array}{l}\text { Exploring the future of ecological } \\
\text { genomics: Integrating CTA with } \\
\text { vision assessment }\end{array}$ & 2008 & $\begin{array}{l}\text { Technological } \\
\text { Forecasting } \\
\text { and Social } \\
\text { Change }\end{array}$ & 22 & & & K \\
\hline $\begin{array}{l}\text { Fenwick D., } \\
\text { Daim T.U., } \\
\text { Gerdsri N. }\end{array}$ & $\begin{array}{l}\text { Value Driven Technology Road } \\
\text { Mapping (VTRM) process } \\
\text { integrating decision making and } \\
\text { marketing tools: Case of Internet } \\
\text { security technologies }\end{array}$ & 2009 & $\begin{array}{l}\text { Technological } \\
\text { Forecasting } \\
\text { and Social } \\
\text { Change }\end{array}$ & 39 & $\mathrm{P}$ & & \\
\hline $\begin{array}{l}\text { Tuominen A., } \\
\text { Ahlqvist T. }\end{array}$ & $\begin{array}{l}\text { Is the transport system becoming } \\
\text { ubiquitous? Socio-technical } \\
\text { roadmapping as a tool for } \\
\text { integrating the development of } \\
\text { transport policies and intelligent } \\
\text { transport systems and services in } \\
\text { Finland }\end{array}$ & 2010 & $\begin{array}{l}\text { Technological } \\
\text { Forecasting } \\
\text { and Social } \\
\text { Change }\end{array}$ & 31 & & & $\mathrm{~K}$ \\
\hline $\begin{array}{l}\text { Wirth S., } \\
\text { Markard J. }\end{array}$ & $\begin{array}{l}\text { Context matters: How existing } \\
\text { sectors and competing } \\
\text { technologies affect the prospects } \\
\text { of the Swiss Bio-SNG innovation } \\
\text { system }\end{array}$ & 2011 & $\begin{array}{l}\text { Technological } \\
\text { Forecasting } \\
\text { and Social } \\
\text { Change }\end{array}$ & 26 & & $\mathrm{O}$ & \\
\hline $\begin{array}{l}\text { Wu F.-S., } \\
\text { Hsu C.-C., } \\
\text { Lee P.-C., } \\
\text { Su H.-N. }\end{array}$ & $\begin{array}{l}\text { A systematic approach for } \\
\text { integrated trend analysis-The case } \\
\text { of etching }\end{array}$ & 2011 & \begin{tabular}{|l|} 
Technological \\
Forecasting \\
and Social \\
Change \\
\end{tabular} & 10 & & & K \\
\hline $\begin{array}{l}\text { Nahuis R., } \\
\text { Moors E.H.M., } \\
\text { Smits R.E.H.M. }\end{array}$ & $\begin{array}{l}\text { User producer interaction in } \\
\text { context }\end{array}$ & 2012 & $\begin{array}{l}\text { Technological } \\
\text { Forecasting } \\
\text { and Social } \\
\text { Change }\end{array}$ & 11 & & & $\mathrm{~K}$ \\
\hline $\begin{array}{l}\text { Lin H.-C., } \\
\text { Luarn P., } \\
\text { Maa R.-H., } \\
\text { Chen C.-W. }\end{array}$ & $\begin{array}{l}\text { Adaptive foresight modular } \\
\text { design and dynamic adjustment } \\
\text { mechanism: Framework and } \\
\text { Taiwan case study }\end{array}$ & 2012 & $\begin{array}{l}\text { Technological } \\
\text { Forecasting } \\
\text { and Social } \\
\text { Change }\end{array}$ & 2 & & & $\mathrm{~K}$ \\
\hline $\begin{array}{l}\text { Routley M., } \\
\text { Phaal R., } \\
\text { Probert D. }\end{array}$ & $\begin{array}{l}\text { Exploring industry dynamics and } \\
\text { interactions }\end{array}$ & 2013 & $\begin{array}{l}\text { Technological } \\
\text { Forecasting } \\
\text { and Social } \\
\text { Change }\end{array}$ & 13 & & $\mathrm{O}$ & \\
\hline
\end{tabular}




\begin{tabular}{|c|c|c|c|c|c|c|c|}
\hline $\begin{array}{l}\text { Stolwijk C.C.M., } \\
\text { Ortt J.R., } \\
\text { den Hartigh E. }\end{array}$ & $\begin{array}{l}\text { The joint evolution of alliance } \\
\text { networks and technology: A } \\
\text { survey of the empirical literature }\end{array}$ & 2013 & $\begin{array}{l}\text { Technological } \\
\text { Forecasting } \\
\text { and Social } \\
\text { Change }\end{array}$ & 7 & $\mathrm{P}$ & & \\
\hline $\begin{array}{l}\text { Probert D., } \\
\text { Dissel M., } \\
\text { Farrukh C., } \\
\text { Mortara L., } \\
\text { Thorn V., } \\
\text { Phaal R. } \\
\end{array}$ & $\begin{array}{l}\text { The process of making the } \\
\text { business case for technology: A } \\
\text { sales and marketing perspective } \\
\text { for technologists }\end{array}$ & 2013 & $\begin{array}{l}\text { Technological } \\
\text { Forecasting } \\
\text { and Social } \\
\text { Change }\end{array}$ & 5 & $\mathrm{P}$ & & \\
\hline $\begin{array}{l}\text { Compagna D., } \\
\text { Kohlbacher F. }\end{array}$ & $\begin{array}{l}\text { The limits of participatory } \\
\text { technology development: The } \\
\text { case of service robots in care } \\
\text { facilities for older people }\end{array}$ & 2015 & $\begin{array}{l}\text { Technological } \\
\text { Forecasting } \\
\text { and Social } \\
\text { Change }\end{array}$ & 10 & & $\mathrm{O}$ & \\
\hline $\begin{array}{l}\text { Wang X., } \\
\text { Qiu P., } \\
\text { Zhu D., } \\
\text { Mitkova L., } \\
\text { Lei M., } \\
\text { Porter A.L. }\end{array}$ & $\begin{array}{l}\text { Identification of technology } \\
\text { development trends based on } \\
\text { subject-action-object analysis: } \\
\text { The case of dye-sensitized solar } \\
\text { cells }\end{array}$ & 2015 & $\begin{array}{l}\text { Technological } \\
\text { Forecasting } \\
\text { and Social } \\
\text { Change }\end{array}$ & 9 & $\mathrm{P}$ & & \\
\hline Gao P. & $\begin{array}{l}\text { Government in the catching-up of } \\
\text { technology innovation: Case of } \\
\text { administrative intervention in } \\
\text { China }\end{array}$ & 2015 & $\begin{array}{l}\text { Technological } \\
\text { Forecasting } \\
\text { and Social } \\
\text { Change }\end{array}$ & 7 & & $\mathrm{O}$ & \\
\hline $\begin{array}{l}\text { Sierzchula W., } \\
\text { Nemet G. }\end{array}$ & $\begin{array}{l}\text { Using patents and prototypes for } \\
\text { preliminary evaluation of } \\
\text { technology-forcing policies: } \\
\text { Lessons from California's Zero } \\
\text { Emission Vehicle regulations }\end{array}$ & 2015 & $\begin{array}{l}\text { Technological } \\
\text { Forecasting } \\
\text { and Social } \\
\text { Change }\end{array}$ & 1 & & & K \\
\hline $\begin{array}{l}\text { Markard J., } \\
\text { Hoffmann V.H. }\end{array}$ & $\begin{array}{l}\text { Analysis of complementarities: } \\
\text { Framework and examples from } \\
\text { the energy transition }\end{array}$ & 2016 & $\begin{array}{l}\text { Technological } \\
\text { Forecasting } \\
\text { and Social } \\
\text { Change }\end{array}$ & 3 & $P$ & & \\
\hline $\begin{array}{l}\text { Zhang G., } \\
\text { Zhou J. }\end{array}$ & $\begin{array}{l}\text { The effects of forward and } \\
\text { reverse engineering on firm } \\
\text { innovation performance in the } \\
\text { stages of technology catch-up: } \\
\text { An empirical study of China }\end{array}$ & 2016 & $\begin{array}{l}\text { Technological } \\
\text { Forecasting } \\
\text { and Social } \\
\text { Change }\end{array}$ & 2 & $\mathrm{P}$ & & \\
\hline $\begin{array}{l}\text { Grafström J., } \\
\text { Lindman } \AA .\end{array}$ & $\begin{array}{l}\text { Invention, innovation and } \\
\text { diffusion in the European wind } \\
\text { power sector }\end{array}$ & 2017 & $\begin{array}{l}\text { Technological } \\
\text { Forecasting } \\
\text { and Social } \\
\text { Change }\end{array}$ & 3 & & & K \\
\hline Proskuryakova L. & $\begin{array}{l}\text { Energy technology foresight in } \\
\text { emerging economies }\end{array}$ & 2017 & $\begin{array}{l}\text { Technological } \\
\text { Forecasting } \\
\text { and Social } \\
\text { Change }\end{array}$ & 1 & $\mathrm{P}$ & & \\
\hline $\begin{array}{l}\text { Ghazinoory S., } \\
\text { Dastranj N., } \\
\text { Saghafi F., } \\
\text { Kulshreshtha A., } \\
\text { Hasanzadeh A. }\end{array}$ & $\begin{array}{l}\text { Technology roadmapping } \\
\text { architecture based on } \\
\text { technological learning: Case } \\
\text { study of social banking in Iran }\end{array}$ & 2017 & $\begin{array}{l}\text { Technological } \\
\text { Forecasting } \\
\text { and Social } \\
\text { Change }\end{array}$ & 0 & $\mathrm{P}$ & & \\
\hline $\begin{array}{l}\text { Su H.-N., } \\
\text { Moaniba I.M. }\end{array}$ & $\begin{array}{l}\text { Investigating the dynamics of } \\
\text { interdisciplinary evolution in } \\
\text { technology developments }\end{array}$ & 2017 & $\begin{array}{l}\text { Technological } \\
\text { Forecasting } \\
\text { and Social } \\
\text { Change }\end{array}$ & 0 & & & K \\
\hline Chang S.-H. & $\begin{array}{l}\text { The technology networks and } \\
\text { development trends of university- } \\
\text { industry collaborative patents }\end{array}$ & 2017 & $\begin{array}{l}\text { Technological } \\
\text { Forecasting } \\
\text { and Social } \\
\text { Change }\end{array}$ & 0 & & $\mathrm{O}$ & \\
\hline
\end{tabular}




\begin{tabular}{|c|c|c|c|c|c|c|c|}
\hline $\begin{array}{l}\text { Madsen H.M., } \\
\text { Brown R., } \\
\text { Elle M., } \\
\text { Mikkelsen P.S. }\end{array}$ & $\begin{array}{l}\text { Social construction of stormwater } \\
\text { control measures in Melbourne } \\
\text { and Copenhagen: A discourse } \\
\text { analysis of technological change, } \\
\text { embedded meanings and potential } \\
\text { mainstreaming }\end{array}$ & 2017 & $\begin{array}{l}\text { Technological } \\
\text { Forecasting } \\
\text { and Social } \\
\text { Change }\end{array}$ & 0 & & $\mathrm{O}$ & \\
\hline $\begin{array}{l}\text { Roessner J.D., } \\
\text { Porter A.L., } \\
\text { Xu H. }\end{array}$ & $\begin{array}{l}\text { National Capacities to Absorb } \\
\text { and Institutionalize External } \\
\text { Science and Technology }\end{array}$ & 1992 & $\begin{array}{l}\text { Technology } \\
\text { Analysis \& } \\
\text { Strategic } \\
\text { Management } \\
\end{array}$ & 19 & $\mathrm{P}$ & & \\
\hline Genus A. & $\begin{array}{l}\text { Political Construction and } \\
\text { Control of Technology: Wave- } \\
\text { power Renewable Energy } \\
\text { Technologies }\end{array}$ & 1993 & $\begin{array}{l}\text { Technology } \\
\text { Analysis \& } \\
\text { Strategic } \\
\text { Management } \\
\end{array}$ & 4 & & & K \\
\hline $\begin{array}{l}\text { Debackere K., } \\
\text { Clarysse B., } \\
\text { Wijnberg N.M., } \\
\text { Rappa M.A. }\end{array}$ & $\begin{array}{l}\text { Science and Industry: A Theory } \\
\text { of Networks and Paradigms }\end{array}$ & 1994 & $\begin{array}{l}\text { Technology } \\
\text { Analysis \& } \\
\text { Strategic } \\
\text { Management }\end{array}$ & 31 & & $\mathrm{O}$ & \\
\hline $\begin{array}{l}\text { Den Hond F., } \\
\text { Groenewegen P. }\end{array}$ & $\begin{array}{l}\text { Environmental technology } \\
\text { foresight: New horizons for } \\
\text { technology management }\end{array}$ & 1996 & $\begin{array}{l}\text { Technology } \\
\text { Analysis \& } \\
\text { Strategic } \\
\text { Management } \\
\end{array}$ & 8 & $\mathrm{P}$ & & \\
\hline Fleck J. & $\begin{array}{l}\text { Contingent knowledge and } \\
\text { technology development }\end{array}$ & 1997 & $\begin{array}{l}\text { Technology } \\
\text { Analysis \& } \\
\text { Strategic } \\
\text { Management } \\
\end{array}$ & 53 & & & K \\
\hline $\begin{array}{l}\text { Jørgensen U., } \\
\text { Sørensen O.H. }\end{array}$ & $\begin{array}{l}\text { Arenas of development - A space } \\
\text { populated by actor-worlds, } \\
\text { artefacts, and surprises }\end{array}$ & 1999 & $\begin{array}{l}\text { Technology } \\
\text { Analysis \& } \\
\text { Strategic } \\
\text { Management } \\
\end{array}$ & 23 & $P$ & & \\
\hline Schot J. & $\begin{array}{l}\text { Towards new forms of } \\
\text { participatory technology } \\
\text { development }\end{array}$ & 2001 & $\begin{array}{l}\text { Technology } \\
\text { Analysis \& } \\
\text { Strategic } \\
\text { Management } \\
\end{array}$ & 75 & P & & \\
\hline Lin H.-M. & $\begin{array}{l}\text { How technology policy facilitates } \\
\text { technology diffusion and } \\
\text { improves firm capability: A } \\
\text { dynamic survey from a network } \\
\text { perspective }\end{array}$ & 2009 & $\begin{array}{l}\text { Technology } \\
\text { Analysis \& } \\
\text { Strategic } \\
\text { Management }\end{array}$ & 4 & & $\mathrm{O}$ & \\
\hline $\begin{array}{l}\text { Huang L., } \\
\text { Guo Y., } \\
\text { Peng Z., } \\
\text { Porter A.L. }\end{array}$ & $\begin{array}{l}\text { Characterising a technology } \\
\text { development at the stage of early } \\
\text { emerging applications: } \\
\text { Nanomaterial-enhanced } \\
\text { biosensors }\end{array}$ & 2011 & $\begin{array}{l}\text { Technology } \\
\text { Analysis \& } \\
\text { Strategic } \\
\text { Management }\end{array}$ & 15 & $\mathrm{P}$ & & \\
\hline Tsuji Y.S. & $\begin{array}{l}\text { Profiling technology } \\
\text { development process using patent } \\
\text { data analysis: A case study }\end{array}$ & 2012 & $\begin{array}{l}\text { Technology } \\
\text { Analysis \& } \\
\text { Strategic } \\
\text { Management } \\
\end{array}$ & 5 & $\mathrm{P}$ & & \\
\hline $\begin{array}{l}\text { Zhang Y., } \\
\text { Guo Y., } \\
\text { Wang X., } \\
\text { Zhu D., } \\
\text { Porter A.L. }\end{array}$ & $\begin{array}{l}\text { A hybrid visualisation model for } \\
\text { technology roadmapping: } \\
\text { Bibliometrics, qualitative } \\
\text { methodology and empirical study }\end{array}$ & 2013 & $\begin{array}{l}\text { Technology } \\
\text { Analysis \& } \\
\text { Strategic } \\
\text { Management }\end{array}$ & 18 & $\mathrm{P}$ & & \\
\hline $\begin{array}{l}\text { Gerdsri N., } \\
\text { Kongthon A., } \\
\text { Vatananan R.S. }\end{array}$ & $\begin{array}{l}\text { Mapping the knowledge } \\
\text { evolution and professional } \\
\text { network in the field of technology } \\
\text { roadmapping: A bibliometric } \\
\text { analysis }\end{array}$ & 2013 & $\begin{array}{l}\text { Technology } \\
\text { Analysis \& } \\
\text { Strategic } \\
\text { Management }\end{array}$ & 14 & & & K \\
\hline $\begin{array}{l}\text { Leenders } \\
\text { M.A.A.M., Chandra } \\
\text { Y. }\end{array}$ & $\begin{array}{l}\text { Antecedents and consequences of } \\
\text { green innovation in the wine } \\
\text { industry: The role of channel } \\
\text { structure }\end{array}$ & 2013 & $\begin{array}{l}\text { Technology } \\
\text { Analysis \& } \\
\text { Strategic } \\
\text { Management }\end{array}$ & 10 & & & $\mathrm{~K}$ \\
\hline
\end{tabular}




\begin{tabular}{|c|c|c|c|c|c|c|c|}
\hline $\begin{array}{l}\text { Jacobs C.D., } \\
\text { Steyaert C., } \\
\text { Überbacher F. }\end{array}$ & $\begin{array}{l}\text { Anticipating intended users: } \\
\text { Prospective sensemaking in } \\
\text { technology development }\end{array}$ & 2013 & $\begin{array}{l}\text { Technology } \\
\text { Analysis \& } \\
\text { Strategic } \\
\text { Management }\end{array}$ & 1 & $\mathrm{P}$ & & \\
\hline $\begin{array}{l}\text { Ma T., } \\
\text { Porter A.L., } \\
\text { Guo Y., } \\
\text { Ready J., } \\
\text { Xu C., } \\
\text { Gao L. }\end{array}$ & $\begin{array}{l}\text { A technology opportunities } \\
\text { analysis model: applied to dye- } \\
\text { sensitised solar cells for China }\end{array}$ & 2014 & $\begin{array}{l}\text { Technology } \\
\text { Analysis \& } \\
\text { Strategic } \\
\text { Management }\end{array}$ & 6 & $\mathrm{P}$ & & \\
\hline $\begin{array}{l}\text { Banerjee S., } \\
\text { Sharma A.K. }\end{array}$ & $\begin{array}{l}\text { Co-creation as a risk-sharing } \\
\text { strategy for the development of } \\
\text { innovative EUV lithography } \\
\text { technology in the semiconductor } \\
\text { industry }\end{array}$ & 2015 & $\begin{array}{l}\text { Technology } \\
\text { Analysis \& } \\
\text { Strategic } \\
\text { Management }\end{array}$ & 0 & & & K \\
\hline Choi H. & $\begin{array}{l}\text { Ready-steady-go for emerging } \\
\text { technologies in post catch-up } \\
\text { countries: a longitudinal network } \\
\text { analysis of nanotech in Korea }\end{array}$ & 2017 & $\begin{array}{l}\text { Technology } \\
\text { Analysis \& } \\
\text { Strategic } \\
\text { Management }\end{array}$ & 0 & & & K \\
\hline $\begin{array}{l}\text { Bae Z.-t., } \\
\text { Lee J. }\end{array}$ & $\begin{array}{l}\text { Technology development patterns } \\
\text { of small and medium sized } \\
\text { companies in the Korean } \\
\text { machinery industry }\end{array}$ & 1986 & Technovation & 11 & $\mathrm{P}$ & & \\
\hline Thomas S. & $\begin{array}{l}\text { The development and appraisal of } \\
\text { nuclear power. Part II. The role } \\
\text { of technical change }\end{array}$ & 1988 & Technovation & 5 & & & K \\
\hline Whitman C.I. & $\begin{array}{l}\text { Managing technology } \\
\text { development: perspectives of a } \\
\text { practitioner }\end{array}$ & 1989 & Technovation & 2 & & $\mathrm{O}$ & \\
\hline $\begin{array}{l}\text { Crow M.M., } \\
\text { Nath S. }\end{array}$ & $\begin{array}{l}\text { Technology strategy development } \\
\text { in Japanese industry: an } \\
\text { assessment of market and } \\
\text { government influences }\end{array}$ & 1990 & Technovation & 3 & & & K \\
\hline $\begin{array}{l}\text { Crow M.M., } \\
\text { Nath S.A. }\end{array}$ & $\begin{array}{l}\text { Technology strategy development } \\
\text { in Korean industry: an } \\
\text { assessment of market and } \\
\text { government influences }\end{array}$ & 1992 & Technovation & 5 & & & K \\
\hline Howarth C.S. & $\begin{array}{l}\text { The role of strategic alliances in } \\
\text { the development of technology }\end{array}$ & 1994 & Technovation & 12 & & $\mathrm{O}$ & \\
\hline Molina A.H. & $\begin{array}{l}\text { Understanding the role of the } \\
\text { technical in the build-up of } \\
\text { sociotechnical constituencies }\end{array}$ & 1998 & Technovation & 26 & $\mathrm{P}$ & & \\
\hline Phillimore J. & $\begin{array}{l}\text { Beyond the linear view of } \\
\text { innovation in science park } \\
\text { evaluation. An analysis of } \\
\text { Western Australian Technology } \\
\text { Park }\end{array}$ & 1999 & Technovation & 77 & & & K \\
\hline $\begin{array}{l}\text { Drejer A., } \\
\text { Riis J.O. }\end{array}$ & $\begin{array}{l}\text { Competence development and } \\
\text { technology: How learning and } \\
\text { technology can be meaningfully } \\
\text { integrated }\end{array}$ & 1999 & Technovation & 32 & $\mathrm{P}$ & & \\
\hline $\begin{array}{l}\text { Platt L., } \\
\text { Wilson G. }\end{array}$ & $\begin{array}{l}\text { Technology development and the } \\
\text { poor/marginalized: Context, } \\
\text { intervention and participation }\end{array}$ & 1999 & Technovation & 15 & & & K \\
\hline $\begin{array}{l}\text { Liu H., } \\
\text { Jiang Y. }\end{array}$ & $\begin{array}{l}\text { Technology transfer from higher } \\
\text { education institutions to industry } \\
\text { in China: Nature and implications }\end{array}$ & 2001 & Technovation & 52 & $\mathrm{P}$ & & \\
\hline $\begin{array}{l}\text { Stock G.N., } \\
\text { McDermott C.M. }\end{array}$ & $\begin{array}{l}\text { Organizational and strategic } \\
\text { predictors of manufacturing } \\
\text { technology implementation } \\
\text { success: An exploratory study }\end{array}$ & 2001 & Technovation & 24 & & $\mathrm{O}$ & \\
\hline
\end{tabular}




\begin{tabular}{|c|c|c|c|c|c|c|c|}
\hline $\begin{array}{l}\text { Takayama M., } \\
\text { Watanabe C., } \\
\text { Griffy-Brown C. }\end{array}$ & $\begin{array}{l}\text { Remaining innovative without } \\
\text { sacrificing stability: An analysis } \\
\text { of strategies in the Japanese } \\
\text { pharmaceutical industry that } \\
\text { enable firms to overcome inertia } \\
\text { resulting from successful market } \\
\text { penetration of new product } \\
\text { development }\end{array}$ & 2002 & Technovation & 10 & & $\mathrm{O}$ & \\
\hline $\begin{array}{l}\text { Gil Y., } \\
\text { Bong S., } \\
\text { Lee J. }\end{array}$ & \begin{tabular}{|l|} 
Integration model of technology \\
internalization modes and \\
learning strategy: Globally late \\
starter Samsung's successful \\
practices in South Korea \\
\end{tabular} & 2003 & Technovation & 10 & & & K \\
\hline Narula R. & $\begin{array}{l}\text { R\&D collaboration by SMEs: } \\
\text { New opportunities and limitations } \\
\text { in the face of globalisation }\end{array}$ & 2004 & Technovation & 204 & & $\mathrm{O}$ & \\
\hline Pilkington A. & $\begin{array}{l}\text { Technology portfolio alignment } \\
\text { as an indicator of } \\
\text { commercialisation: An } \\
\text { investigation of fuel cell } \\
\text { patenting }\end{array}$ & 2004 & Technovation & 34 & & & K \\
\hline Hsu C.-W. & $\begin{array}{l}\text { Formation of industrial } \\
\text { innovation mechanisms through } \\
\text { the research institute }\end{array}$ & 2005 & Technovation & 20 & & $\mathrm{O}$ & \\
\hline $\begin{array}{l}\text { Mohan S.R., } \\
\text { Rao A.R. }\end{array}$ & $\begin{array}{l}\text { Strategy for technology } \\
\text { development in public R\&D } \\
\text { institutes by partnering with the } \\
\text { industry }\end{array}$ & 2005 & Technovation & 12 & & $\mathrm{O}$ & \\
\hline $\begin{array}{l}\text { Wang T.-Y., } \\
\text { Chien S.-C. }\end{array}$ & $\begin{array}{l}\text { The influences of technology } \\
\text { development on economic } \\
\text { performance-The example of } \\
\text { ASEAN countries }\end{array}$ & 2007 & Technovation & 31 & $\mathrm{P}$ & & \\
\hline Johnson W.H.A. & $\begin{array}{l}\text { Roles, resources and benefits of } \\
\text { intermediate organizations } \\
\text { supporting triple helix } \\
\text { collaborative R\&D: The case of } \\
\text { Precarn }\end{array}$ & 2008 & Technovation & 43 & & $\mathrm{O}$ & \\
\hline $\begin{array}{l}\text { Caetano M., } \\
\text { Amaral D.C. }\end{array}$ & $\begin{array}{l}\text { Roadmapping for technology } \\
\text { push and partnership: A } \\
\text { contribution for open innovation } \\
\text { environments }\end{array}$ & 2011 & Technovation & 35 & & $\mathrm{O}$ & \\
\hline $\begin{array}{l}\text { Lu W.-M., } \\
\text { Hung S.-W. }\end{array}$ & $\begin{array}{l}\text { Exploring the operating } \\
\text { efficiency of Technology } \\
\text { Development Programs by an } \\
\text { intellectual capital perspective - } \\
\text { A case study of Taiwan }\end{array}$ & 2011 & Technovation & 22 & & $\mathrm{O}$ & \\
\hline $\begin{array}{l}\text { Köhler A.R., } \\
\text { Som C. }\end{array}$ & $\begin{array}{l}\text { Risk preventative innovation } \\
\text { strategies for emerging } \\
\text { technologies the cases of nano- } \\
\text { textiles and smart textiles }\end{array}$ & 2014 & Technovation & 9 & & & K \\
\hline $\begin{array}{l}\text { Cohen B., } \\
\text { Ernesto Amorós J. }\end{array}$ & $\begin{array}{l}\text { Municipal demand-side policy } \\
\text { tools and the strategic } \\
\text { management of technology life } \\
\text { cycles }\end{array}$ & 2014 & Technovation & 7 & & $\mathrm{O}$ & \\
\hline $\begin{array}{l}\text { Soetanto D., } \\
\text { Jack S. }\end{array}$ & $\begin{array}{l}\text { The impact of university-based } \\
\text { incubation support on the } \\
\text { innovation strategy of academic } \\
\text { spin-offs }\end{array}$ & 2016 & Technovation & 5 & & $\mathrm{O}$ & \\
\hline
\end{tabular}

